The Canadian Mineralogist

Vol. 42, pp. 1179-1204 (2004)

\title{
ZONING IN THE KIRKA BORATE DEPOSIT, WESTERN TURKEY: PRIMARY EVAPORITIC FRACTIONATION OR DIAGENETIC MODIFICATIONS?
}

\author{
САніт HELVACI ${ }^{\S}$ \\ Dokuz Eylül Üniversitesi, Mühendislik Fakültesi, Jeoloji Mühendisliği Bölümü, 35100, Bornova-İzmir, Turkey
}

FEDERICO ORTÍ II

Departament de Geoquímica, Petrologia i Prospecció Geológica, Facultat de Geologia, Universitat de Barcelona, Martí i Franquès s/n, E-08028 Barcelona, Spain

\begin{abstract}
The Kırka borate deposit (Miocene), in western Turkey, the most important $\mathrm{B}_{2} \mathrm{O}_{3}$ producer at present in the world, exhibits a symmetrical zonation in a lateral sense; it is comprised of: a central body of $\mathrm{Na}$ borate (borax), an intermediate zone of $\mathrm{Na}-\mathrm{Ca}$ borate (ulexite), and a marginal zone of $\mathrm{Ca}$ borate (colemanite). This mineral zonation is also developed in a vertical sense, although it is somewhat asymmetrical because of the presence of a discontinuous $\mathrm{Mg}$ borate horizon overlying the central body of borax. The genesis of such a mineral zonation in the Tertiary lacustrine borate deposits of the world has been attributed to a number of diagenetic processes. In contrast, we postulate that the Kırka sequence is merely depositional and represents an evaporitic sequence in a lake basin. The existence of a lateral gradient of salinity in the Kırka lacustrine system would have conditioned the concentric pattern of the facies. The various borax lithofacies (chemical, clastic, mixed) present in the central body reflect precipitation in a lake under evolving conditions. These conditions oscillate from a predominant subaqueous setting at variable depths (perennial lake stage), to an interstitial setting (playa-lake stage). The evaporative concentration of the boratiferous solution in the lake, together with the periodic changes in temperature of the water mass, are considered to be the main controls on the crystallization of borax. No petrographic evidence was found for an inyoite-to-colemanite transformation, as previously proposed. Furthermore, the post-depositional burial of the Kırka deposit is considered to be only moderate, and insufficient for such a generalized transformation. The Mg borates represent the ultimate evaporitic precipitates from the fractionation of the initial boratiferous solution, instead of the reaction products between pre-existing borates and groundwaters. The mineral zonation in Kırka is primary, not only for borax and ulexite, but also for both the colemanite forming the marginal zone and the Mg borates overlying the central body of borax.
\end{abstract}

Keywords: borates, borax, evaporites, lake, zoned borates, Miocene, Kırka deposit, Turkey.

\section{SOMMAIRE}

Le gisement de borates de Kırka (d'âge miocène), en Turquie occidentale, le producteur le plus important de $\mathrm{B}_{2} \mathrm{O}_{3}$ au monde, fait preuve d'une zonation symétrique latérale; il comprend une masse centrale de borate de $\mathrm{Na}$ (borax), une zone intermédiaire de borate à $\mathrm{Na}-\mathrm{Ca}$ (ulexite), et une zone latérale de borate de $\mathrm{Ca}$ (colemanite). Cette zonation minérale est aussi développée dans un sens vertical, quoique le gisement soit quelque peu asymétrique à cause de la présence d'une couche discontinue à borate de Mg par dessus la masse centrale à borax. L'origine d'une telle zonation dans les gisements lacustres tertiaires du monde a été attribuée à une variété de processus diagénétiques. En revanche, nous proposons que la séquence de Kırka n'est que dépositionnelle, et qu'elle représenterait une séquence évaporitique dans un bassin lacustre. L'existence d'un gradient de salinité latéral dans le système lacustre de Kırka pourrait expliquer l'agencement concentrique des faciès. Les divers lithofaciès à borax (chimique, clastique, mixte) présents dans la zone centrale témoignent d'une précipitation dans un lac sous conditions changeantes. Ces conditions vont de milieu subaqueux prédominant à profondeurs variables (stade d'un lac permanent), à un milieu interstitiel (stade d'un lac playa). La concentration évaporative de la solution boratifère dans ce milieu lacustre, ainsi que les changements périodiques de température de la masse d'eau, auraient exercé les contrôles principaux sur la cristallisation du borax. Nous n'avons trouvé aucun signe pétrographique favorisant une transformation de l'inyoïte à la colemanite, proposée antérieurement. De plus, l'enfouissement du gisement de Kırka suite à la déposition n'aurait été que modérée, et non suffisante pour une telle transformation généralisée. Les borates de magnésium représenteraient les précipités ultimes dus au fractionnement de la solution

§-mail address: cahit.helvaci@deu.edu.tr

II E-mail address: orti@natura.geo.ub.es 
boratée initiale lors de l'évaporation, plutôt que les produits de réaction entre les borates pré-existants et les eaux souterraines. La zonation des minéraux à Kırka est donc primaire, non seulement dans le cas du borax et de l'ulexite, mais aussi dans les cas de la colemanite qui constitue la zone périphérique et des borates de magnésium qui recouvrent la masse centrale de borax.

(Traduit par la Rédaction)

Mots-clés: borates, borax, évaporites, lac, zonation parmi les borates, Miocène, gisement de Kırka, Turquie.

\section{INTRODUCTION}

Borate deposits of sedimentary origin constitute a particular case of lacustrine evaporite formations. In modern non-marine environments, boratiferous bodies generally have small dimensions and a playa-lake setting (Muessig 1966, Alonso 1986, Smith \& Medrano 1996). The most important boratiferous deposits, however, formed in deeper lakes during the Tertiary (Kistler \& Helvac1 1994, Helvac1 \& Alonso 2000). Three major groups of Tertiary borate formations have been distinguished (Smith \& Medrano 1996): (1) $\mathrm{Ca}$ and $\mathrm{Na}-\mathrm{Ca}$ borate formations, characterized by colemanite and ulexite facies, (2) Na borate formations, characterized by borax (and kernite) facies, and (3) Mg borate formations.

Studies of the largest Neogene Na borate lake deposits known at present, including the Kramer deposit in Boron, California, and the Kirka deposit in Turkey, have led investigators to designate them as "zoned" in the literature (Bowser \& Dickson 1966). This term has a chemical and a mineralogical significance, but also involves a facies symmetry both in a lateral and a vertical sense. Thus, the zoned Neogene borate deposits have been described as having an outer envelope of $\mathrm{Ca}$ borates, an intermediate envelope of $\mathrm{Na}-\mathrm{Ca}$ borates, and a core of $\mathrm{Na}$ borates. The origin of such a zonation, however, does not have a simple interpretation. For some authors, e.g., Inan et al. (1973) and Palmer \& Helvacı (1995), it represents a primary depositional feature, whereas for others, e.g., Smith \& Medrano (1996), it is mainly the result of a number of diagenetic reactions that occurred between a pre-existing borate formation (the core) and external solutions (groundwater) seeping into it. Also, the origin of some borate minerals within the zones, either primary or diagenetic, has been the subject of debate. This is the case of colemanite in the outermost zones (Helvaci \& Ortí 1998) and the various Mg-bearing borates developed at the top of some deposits (Crowley 1996).

The Miocene Kirka borate deposit in western Turkey is currently the most active site of borax extraction in the world. The fact that the solubility of borax is more sensitive to thermal variations than that of halite confers to this borate mineral great sedimentological significance (Bowser 1965). This deposit has undergone limited burial since its formation. Without doubt, the lacustrine Kurka borates provide an excellent zoned deposit with which (1) to learn more about the sedimen- tology and diagenesis of borax and borate minerals, in general, (2) to test models about the genesis of the socalled zoned Neogene borate deposits, and (3) to compare this zoned pattern with the models of the most common evaporites (chlorides, sulfates).

\section{Geological and Stratigraphic Setting}

The volcano-sedimentary, non-marine sequence filling the Kirka Basin in western Turkey (Fig. 1A) is Miocene in age. This sequence, $>400 \mathrm{~m}$ thick, rests unconformably on a varied substratum composed of Paleozoic metamorphic rocks, a Mesozoic ophiolitic complex, and Eocene limestones. The sequence (Fig. 1B) is comprised of the following rock-units from base to top (Inan 1972, Helvac1 1977, Sunder 1980): (1) volcanic rocks and tuffs $(80 \mathrm{~m}),(2)$ a lower limestone $(80$ $\mathrm{m}),(3)$ a lower clay horizon with interbedded marls and tuffs $(40 \mathrm{~m}),(4)$ a borate unit $(>70 \mathrm{~m}),(5)$ an upper claystone, with tuff, marl and coal bands $(60 \mathrm{~m}),(6)$ an upper limestone containing cherty marls $(>50 \mathrm{~m})$, and (7) basalt (>30 m).

The borate unit, locally up to $145 \mathrm{~m}$ in thickness, was deposited in a lacustrine setting. The borate layers in this unit are interbedded with claystones and tuffs. The main borate minerals are borax, ulexite and colemanite, which are the ore minerals of the commercialgrade bodies (Table 1). Borates of calcium, sodium, magnesium and strontium are formed in subordinate amounts (Inan et al. 1973, Helvacı 1978, 1983, Çolak 1995). The clay layers are made up of smectite-group minerals, mainly hectorite (Çolak 1995) and subordinate illite and chlorite; these layers also contain some volcanic tuffs (commonly altered to zeolites), quartz, biotite, and feldspar (Helvac1 1983, Helvaci et al. 1993). Dolomite is the main carbonate mineral accompanying the clay; minor amounts of magnesite, strontianite and calcite also are present (Çolak 1995).

The borax unit in the area of the Kurka district constitutes the only sodium borate orebody in Turkey, with a $\mathrm{B}_{2} \mathrm{O}_{3}$ content of $20-25 \%$. The Kurka borate deposit, elongate in a north-south direction, is bounded by faults at the eastern and western parts. The western fault is a normal fault that caused a number of slump features. The borax body is enveloped by a thin ulexite-dominant facies followed outward by a colemanite-dominant facies. Stratigraphic, geomorphological and structural estimates in the borate area and throughout the Kirka 
A
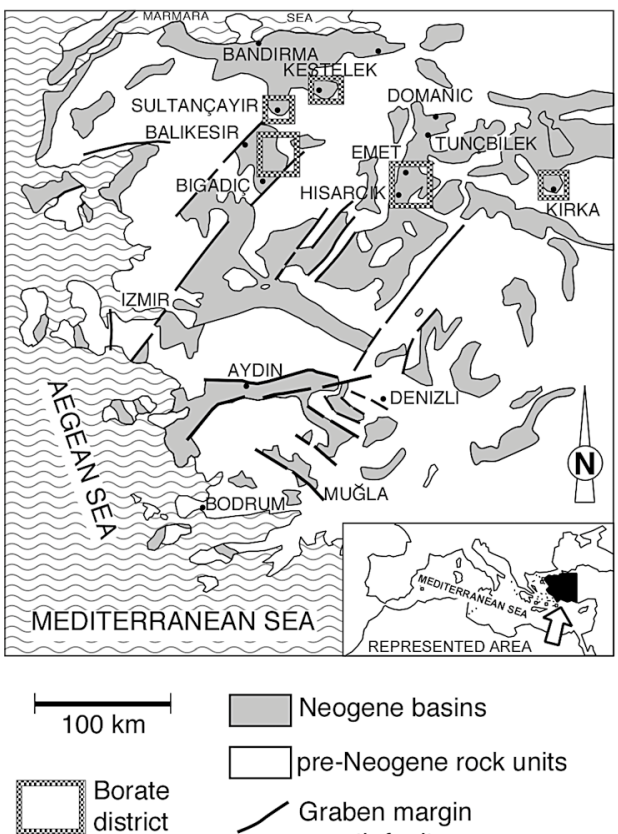

Neogene basins

pre-Neogene rock units

Graben margin

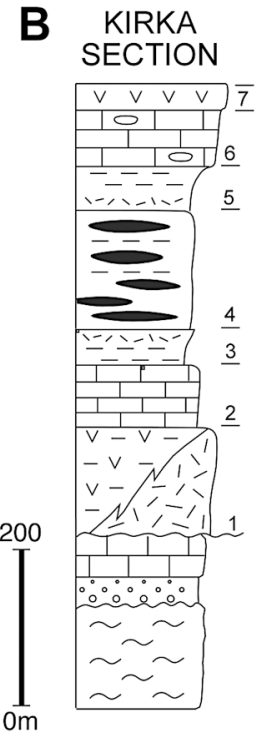

growth fault

\section{LEGEND}

NEOGENE

$v_{\vee} v^{\prime}$ Basalt

\begin{tabular}{ll}
\hline $\bar{v}-$ & $\begin{array}{l}\text { Andesite, rhyolite, } \\
\text { trachyte, agglomerate }\end{array}$
\end{tabular}

ㄴ, Tuff

\begin{tabular}{|l|l|l}
\hline & Limestone
\end{tabular}

\begin{tabular}{|l|l|l|}
\hline 1 & & Cherty limestone \\
\hline 10 &
\end{tabular}

-_-_- Lutite (claystone)

E Boratiferous formation

EOCENE

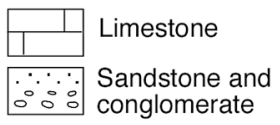

PALAEOZOIC BASEMENT COMPLEX

Ophiolite, marble, schists

$\sim$ Unconformity

FIG. 1. The Kirka borate district in western Turkey. (A) Location of the deposit. The position of other borate districts (Kestelek, Bigadiç, Emet and Sultançayır) in this region is indicated. (B) Stratigraphic section of the Kırka borate deposit. Neogene rock units: 1: Tuffs, 2: Lower limestone, 3: Lower clay, marl and tuff, 4: Borate unit, 5: Upper clay, tuff, marl and coal bands, 6: Upper cherty limestone, 7: Basalt (after Inan et al. 1973, Helvacı 1977, and Sunder 1980).

Basin suggest that the borate formation underwent only moderate burial after its accumulation $(<300 \mathrm{~m})$, as is typical of other borate-bearing Neogene basins in western Turkey (Helvac1 \& Yagmurlu 1995). The boron in the Kirka deposit is assumed to have been derived from the hydrothermal activity associated with intense contemporaneous calc-alkaline volcanism in the region (Inan et al. 1973, Palmer \& Helvac1 1995, Floyd et al. 1998) and the leaching of country rocks, mainly Paleozoic aluminosilicate rocks and Eocene limestones (Palmer \& Helvaci 1997).

\section{Lithofacies Analysis: Previous Investigations}

The first descriptions of the lacustrine Kirka borates were done by Inan (1972) and Inan et al. (1973). These authors described a symmetrical zoning consisting of the following sequence of minerals from base to top: calcite - colemanite - ulexite - borax - ulexite - colemanite - calcite. They considered this zonation to be primary, although the colemanite was interpreted as being derived from the alteration of an inyoite precursor.
Inan et al. (1973) also considered that the primary precipitates are characterized by subhedral to anhedral habits and fine-grained textures, whereas the secondary precipitates are characterized by (1) a euhedral habit and a large size of the crystals, (2) their particular geometries of the facies, and (3) their particular relationships with both the stratification and the other borates. In accordance with this classification, Inan et al. (1973) interpreted as being primary the laminated facies of fine-grained borax laminae $(<1 \mathrm{~cm}$ across), the columnar facies of ulexite, and some fine-grained textures of inyoite. They considered as being secondary the coarsely crystalline borax facies, some facies bearing nodular ulexite, and the minor occurrences of meyerhofferite, tunellite and the $\mathrm{Mg}$ borates.

Palmer \& Helvac1 $(1995,1997)$ carried out isotopic studies on the Kirka borates and concluded that not only ulexite and borax, but also colemanite corresponds to a primary precipitate. Garret (1998) discussed levels of trace-element impurity contents of the borate minerals at Kırka. Çolak (1995) investigated the claystone beds overlying the borax body and determined the minera- 
logical and chemical type of smectite-group minerals characterizing the clay minerals and the associated carbonate minerals (dolomite, calcite, magnesite and strontianite). Ortí \& Helvac1 (2000) proposed the subdivision of the depositional sequence of Kırka into two cycles.

ABLE 1. BORATE MINERALS ENCOUNTERED IN THE KIRKA BORATE DEPOSIT, WESTERN TURKEY

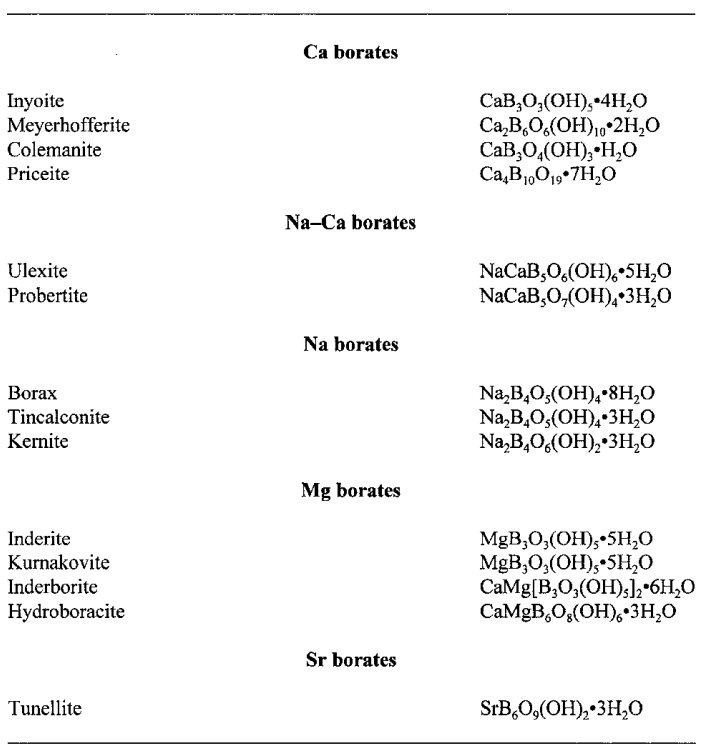

According to the published descriptions, mainly those of Inan et al. (1973) and Helvac1 (1977), the geometrical pattern, the stratigraphic framework, and the distribution of borate facies in the Kirka deposit are shown in Figure 2.

\section{Materials and Methods Used IN THE PRESENT WoRK}

Field studies, stratigraphic observations, facies analysis and sampling were carried out at outcrops and mine galleries in the Kırka borate deposit. Two sections were studied sedimentologically, petrographically and by X-ray diffraction (XRD). Section $1,40 \mathrm{~m}$ in thickness, is located near the Lepçek Stream, in a marginal position of the borate unit, $0.3 \mathrm{~km}$ from an inactive colemanite mine and $2.3 \mathrm{~km}$ from the most active area of the open-pit mine. Section 2, $50 \mathrm{~m}$ in thickness, is located in the thickest part of the open-pit mine (Fig. 2). About 50 samples of borates and carbonates were studied petrographically in large thin sections, and analyzed by XRD.

The samples were powdered in a tungsten carbide ring mill to provide fine powder for whole-rock mineralogy. Diffractograms were run between 2 and $60^{\circ} 2 \theta$ on a Siemens D500 X-ray diffractometer using $\mathrm{CuK \alpha}$ radiation at scan speed $1^{\circ} 2 \theta / \mathrm{min}$.

The petrographic collection of borates was done as follows. Small pieces of rock samples were cut with an oil-refrigerated cutting machine (DISCOPLAN TS) using a low-viscosity oil and a diamond blade $1 \mathrm{~mm}$ in thickness. The thin sections were glued to $5.5 \times 5.4 \mathrm{~cm}$ glass plates using LOCTITE 358 (for glass-glass), which cures rapidly at room temperatures, i.e., in about 1 minute when exposed to UV light (under a UV lamp).

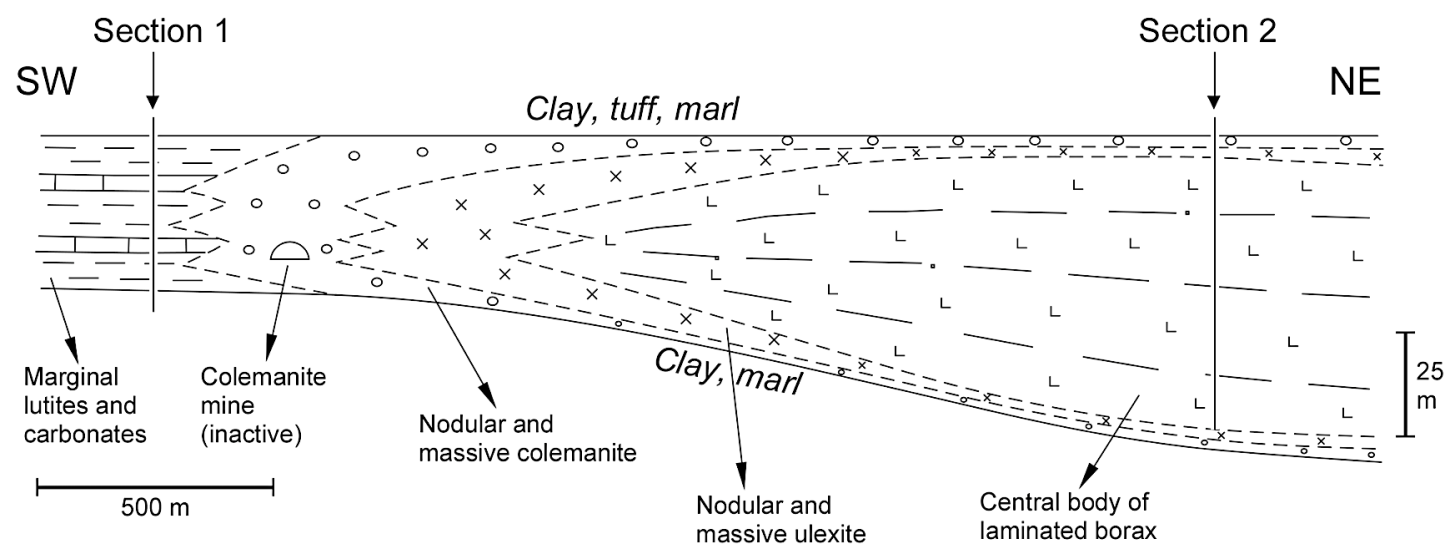

Fig. 2. Interpretative scheme of the distribution of facies in the Kirka borate unit (based on Inan et al. 1973). The location of the two sections studied is indicated; Section 1 is in the marginal part of the deposit, and Section 2 is in the central part of the open-pit mine. Also, the location of an ancient colemanite mine is indicated. 
The Marginal Area of the Borate Unit (SECTION 1)

A representative log of Section 1 is shown in Figure 3. This section is composed of an irregular alternation of beds of claystone, marl, and limestone. Claystone beds are dark brown, soap-like and laminated, and commonly intercalated with very thin (1 to $2 \mathrm{~mm}$ thick) beds of micritic limestone; these limestones may display a micronodular texture. Scarce micronodules of ulexite are enclosed in the claystone beds. Some limestone beds have a massive micritic texture; others have a laminated to stromatolitic appearance. Precursor Ca-bearing borates may be present in this section.

The carbonate minerals found in Section 1 are dolomite with subordinate calcite (XRD). Neomorphic textures in calcite were observed under the microscope in the nodules and micronodules included in the laminated limestones. The same textures occur elsewhere in the limestone beds, together with vug porosity and some

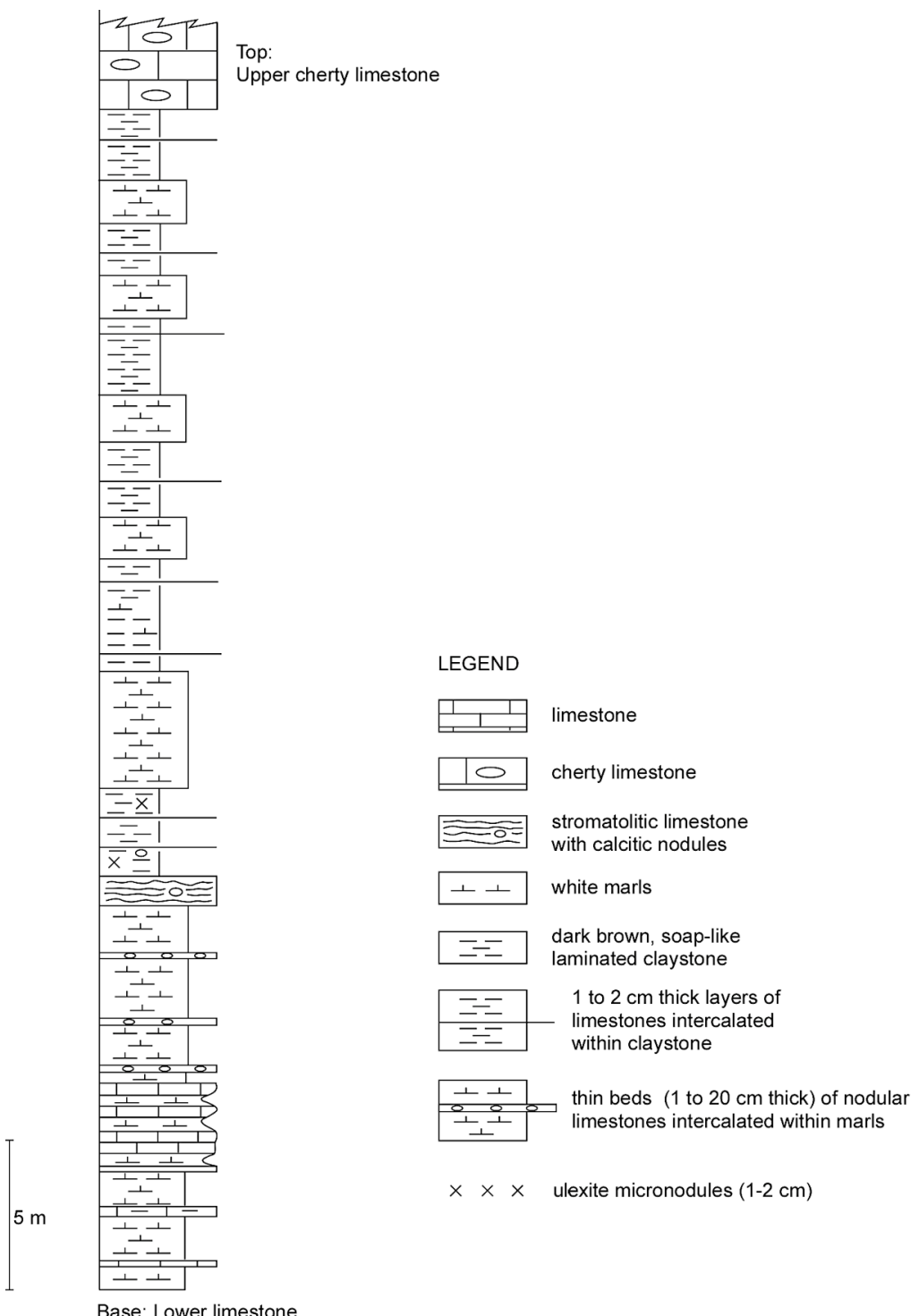

FIG. 3. Lithological log of Section 1, in the marginal part of the Kurka borate unit. 
evidence of recrystallization. It seems likely that these textural features are the result of replacement of (precursor) borate minerals, mainly colemanite or ulexite by calcite.

The mineralogical composition of the soap-like claystone beds was not investigated, but they resemble in color and physical properties the clay beds present at the site of the open-pit mine that we studied (Section 2).
The mineralogy of clay beds in the central part of the open-pit was investigated by Çolak (1995).

Section 1 is the lateral equivalent of the borate layers (including claystone beds) that occupy the central part of the borate unit. In an intermediate position between this central part and Section 1, an ancient mine exploited colemanite layers (Fig. 2).

\section{LEGEND}

LITHOLOGY

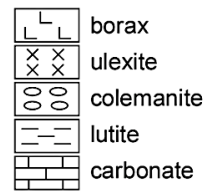

\section{LITHOFACIES/ STRUCTURES \\ borax

\begin{tabular}{l} 
laminated \\
$(1 \mathrm{~mm}-5 \mathrm{~cm})$ \\
\hline $\begin{array}{l}\text { laminated } \\
(1 \mathrm{~mm}-10 \mathrm{~cm})\end{array}$ \\
$\begin{array}{l}\text { macrocrystalline } \\
\text { interstitial }\end{array}$ \\
$\square \quad \begin{array}{c}\text { crystalline } \\
\text { massive }\end{array}$ \\
covered \\
ripples (clastic textures)
\end{tabular} \\ ulexite \\ sifllim nodules \\ $\backsim$ micronodules \\ 0000 columnar-massive}

\section{colemanite}

$\bigcirc \circ$ nodules $(1-15 \mathrm{~cm})$

$\oplus \begin{aligned} & \text { septarian nodules } \\ & \& \text { masses }\end{aligned}$

Accessory minerals (borates)

Tn: tunellite; Kn: kurnakovite $\mathrm{Hb}$ : hydroboracite ; In: inderite
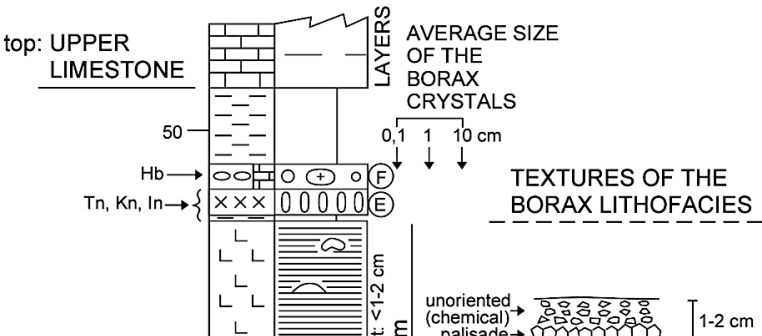

unoriented
(chemical)
palisal

40

$\llcorner\llcorner\llcorner$

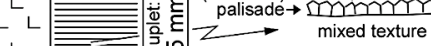

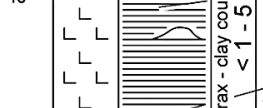

三
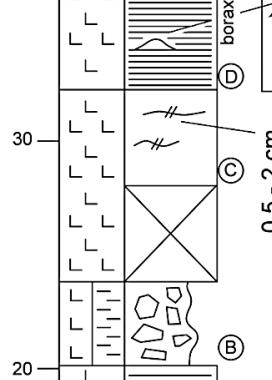

$20-$

$\llcorner L$

$\llcorner\llcorner L$

$\llcorner\llcorner\llcorner$

$L=>\frac{1}{2}$
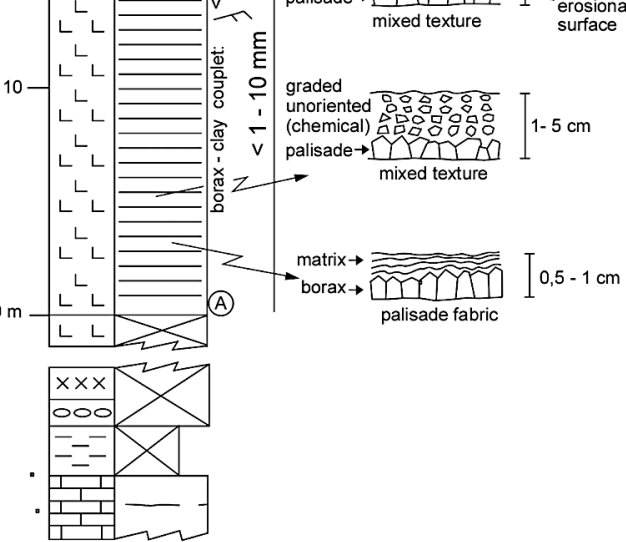

(B)

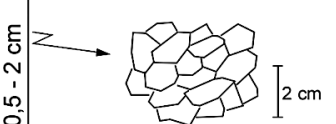
interlocking crystals

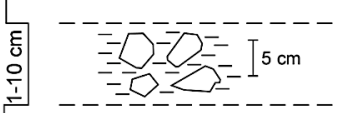

\section{。}

임

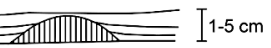
synsedimentary

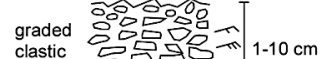

clastic $5080-11-10 \mathrm{~cm}$ palisade $\rightarrow \square \prod I I T+$ dissolution-

CYCLICITY DEPOSITIONAL ENVIRONMENT

Depth (relative)

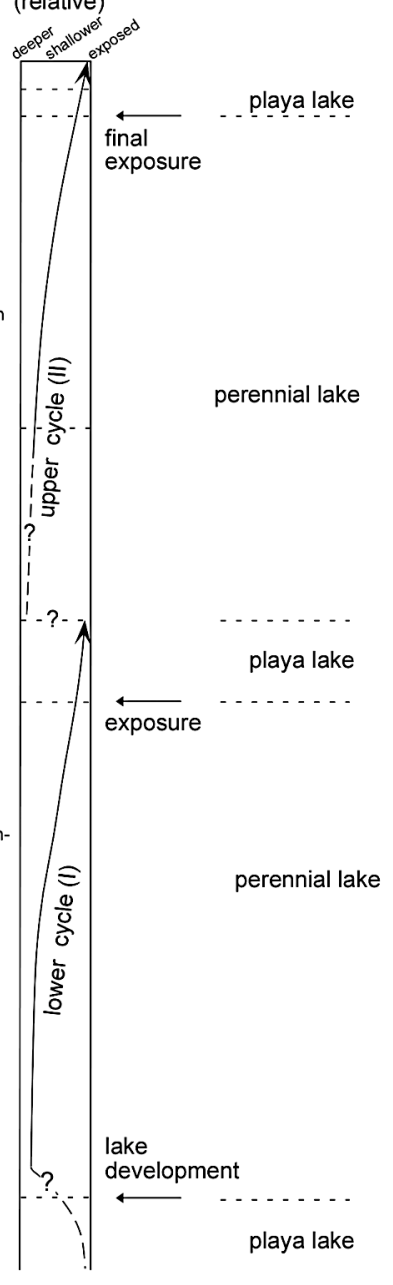

base: LOWER LIMESTONE

FIG. 4. Lithological log of Section 2, in the central part of the Kırka borate unit (modified from Ortí \& Helvacı 2000, Fig. 3). 


\section{The Central Area of the Borate Unit} (SECTION 2)

In this study, the main changes in the mineralogical and facies recognized in Section 2 were differentiated as successive "layers", and arbitrarily labeled from A to $\mathrm{F}$ in ascending order (Fig. 4). Layers A to D correspond to the borax facies, and layers $\mathrm{E}$ and $\mathrm{F}$ correspond to ulexite and colemanite facies, respectively. The underlying layers of ulexite and colemanite (mainly known from boreholes) are not exposed at Section 2 (Fig. 2). Small ripples were observed in some borax layers, but sedimentary structures such as large-scale cross-bedding are not present. Locally, structures resembling desiccation cracks were observed.

\section{Description of the Borax Lithofacies}

The main borax lithofacies found in Section 2 are: laminated borax (layers A and D), macrocrystalline interstitial borax (layer B), and crystalline massive borax (layer C).

\section{Laminated borax}

The predominant lithofacies in the Kırka deposit consists of a rhythmic alternation of borax laminae and lutite laminae. The thickness of a pair of borax-lutite laminae, or couplet, commonly oscillates between $1 \mathrm{~mm}$ and $5 \mathrm{~cm}$, and only rarely goes beyond these limits. Mixed lutite-borax laminae also exist. In the lutite laminae, which commonly have a thickness between $<1$ and $2 \mathrm{~mm}$, the lutitic material has a clayey-dolomitic composition (XRD); these laminae of dolomitic claystone may contain some disseminated crystals of borax.

In the borax laminae, which commonly have a thickness between $1 \mathrm{~mm}$ and $4 \mathrm{~cm}$, the crystals are grey to brownish, range in size from $<1 \mathrm{~mm}$ to $1.5 \mathrm{~cm}$, have a euhedral to subhedral habit, and are zoned owing to the presence of intracrystalline lutitic matrix (as solid inclusions). The presence of this lutitic matrix is variable; in many laminae, it is practically absent (transparent borax), whereas in others, it is very significant (matrixrich borax laminae).

Several textures and fabrics are present in the borax laminae:

(1) In the palisade fabric (Fig. 5A), transparent crystals of borax, up to more than $1 \mathrm{~cm}$ in length, are arranged subvertically. The laminae have an almost planar base and a top that is shaped by the apex of the crystal. The crystals may show truncation surfaces at the top. Toward the top of some of the largest crystals, the presence of both zoned growth (matrix inclusions; Fig. 6A) and inclusions of borax microcrystals (Fig. 6B) are common.
(2) A transparent, unoriented fabric is formed by randomly oriented euhedral to subhedral crystals, in which the size is variable $(<1 \mathrm{~mm}$ to $1 \mathrm{~cm})$ and the matrix content is very low (Fig. 6C). Normal grading can be recognized locally. Some borax crystals show a zonal pattern, and others engulf borax microcrystals poikilitically.

(3) A matrix-rich, unoriented texture with abundant lutitic matrix surrounds the crystals (Fig. 6D). A zonal pattern is common in the borax crystals (Fig. 6D). In this texture, we do not see clear evidence of transport.

(4) A clastic texture of anhedral to subhedral borax crystals commonly displays a chaotic appearance (Fig. $5 \mathrm{~B})$. The sorting varies from good to poor, and the matrix content also is variable. An arrangement subparallel to bedding is displayed by the crystals (Fig. 6E), and normal grading may be present. Small ripples are observed locally. The thickness of the borax laminae may reach up to $4 \mathrm{~cm}$. Gradations between clastic textures and transparent, unoriented textures are commonly recorded, which prevents the differentiation between the two types.

(5) Mixed textures are present and variable. Some are composed of a palisade fabric at the base and one of the above textures at the top; truncation surfaces separating the two textures may occur (Fig. 6F). In some others, the palisade fabric is at the top (Fig. 6G). Other textures display differentiated size and crystal habit from the base to the top.

On a microscopic scale, additional textures of borax and other types of borax microlaminae occur: (a) a platy to tabular texture, which is formed by crystals with rectangular sections resting parallel to bedding (Fig. 6H); (b) an imbricated-like fabric, which is formed by euhedral to rectangular-shaped crystals arranged obliquely to the bedding (Fig. 6I); (c) a sutured texture, in which transparent crystals display sutured contacts; the crystals may be slightly elongate subparallel to the bedding (Fig. 6J); (d) microlaminae with normal grading involve a palisade fabric at the base and finer, transparent crystals at the top; (e) microlaminae in which the crystal size decreases both upward and downward from a maximum at the center. Additional aspects of the borax textures under the microscope are shown in Figure $7 \mathrm{~A}$ to $\mathrm{F}$.

\section{Macrocrystalline interstitial borax}

This lithofacies (layer B) consists of displacive, transparent crystals surrounded by abundant grey lutitic matrix (Figs. 8A, B). These crystals are large (1 to 10 $\mathrm{cm}$ in length), randomly oriented, and may display a zonal growth. This lithofacies forms loose, earthy, matrix-rich beds between 15 and $50 \mathrm{~cm}$ in thickness. These beds may grade into a more cohesive, matrix-poor beds with large euhedral, interlocking crystals of borax resembling a brecciated fabric (Fig. 8B). 

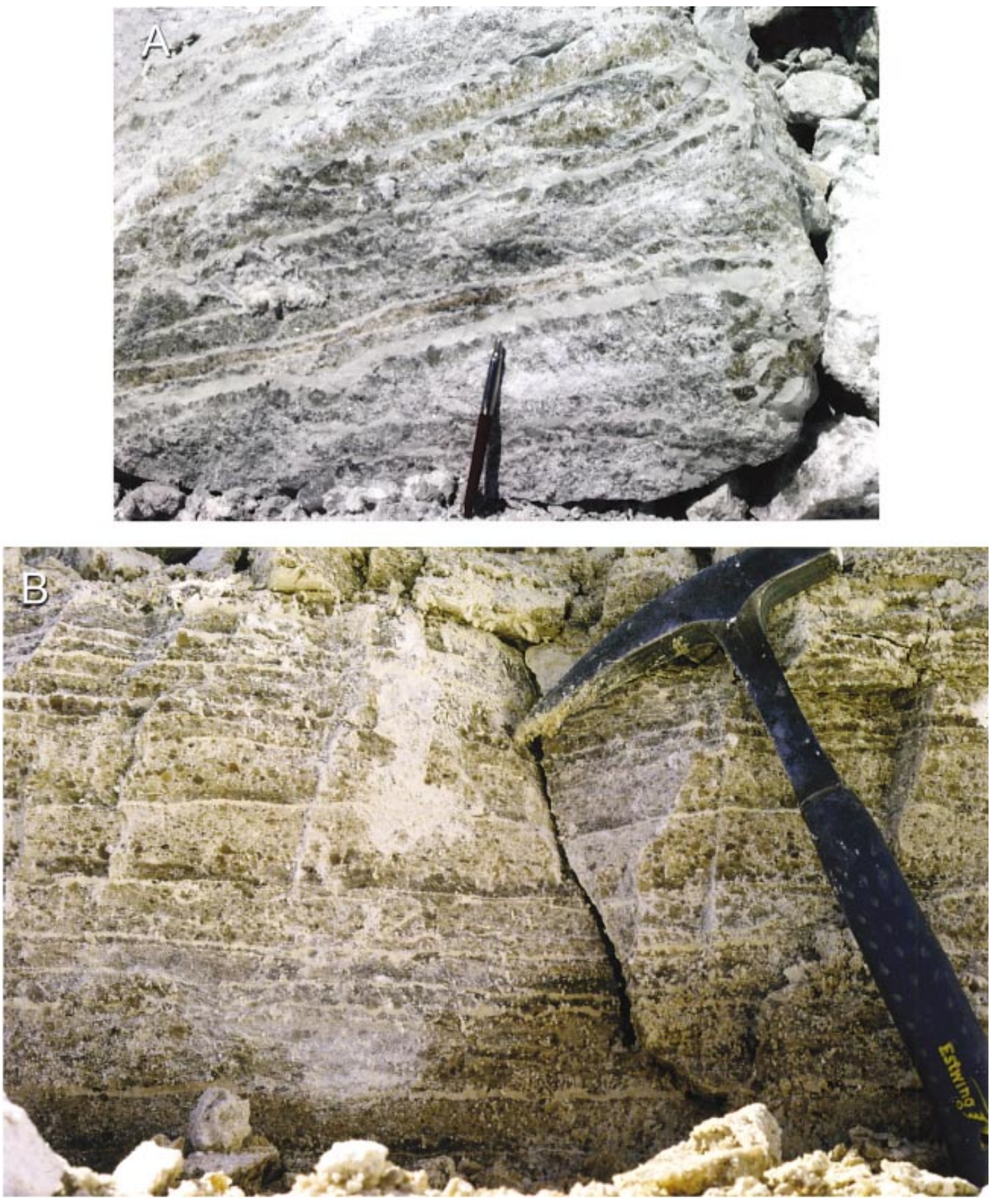

FIG. 5. Laminated borax lithofacies, layer A. A. Palisade fabric in borax laminae. Clear material corresponds to lutitic matrix and laminae (dolomitic claystone). Dark material corresponds to fresh, crystalline borax. The thickness of the borax laminae varies between $1 \mathrm{~mm}$ and about $5 \mathrm{~cm}$. Scale: length of the pen, $14 \mathrm{~cm}$. B. Some of the borax laminae correspond to clastic textures. Others correspond to mixed textures: the thickest borax lamina in the central part of the picture (arrow), up to about $4 \mathrm{~cm}$, displays a palisade fabric (darker color) at the base, and normal grading toward the top. Other borax laminae in the upper part of the picture are composed of a palisade fabric. Hammer for scale. 
A

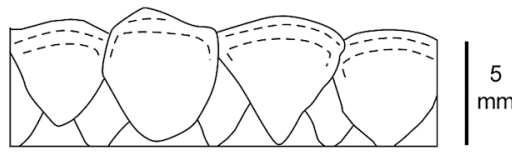

C

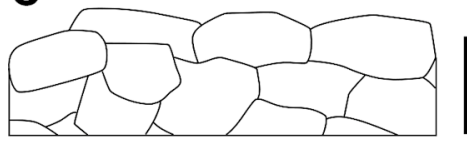

E

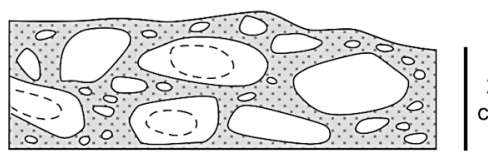

G

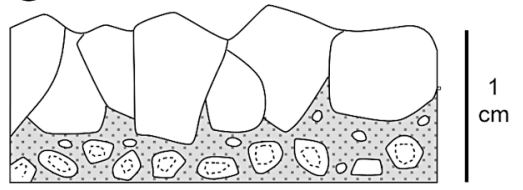

I

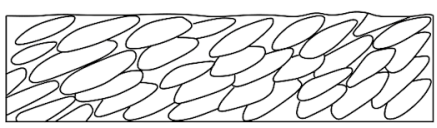

B

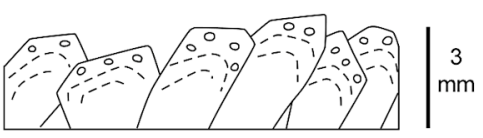

D

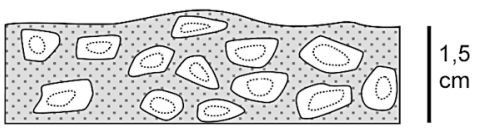

F

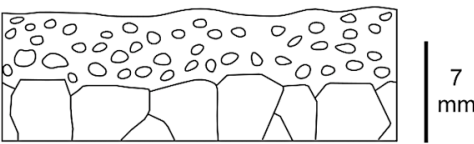

H

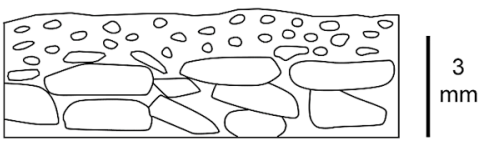

J

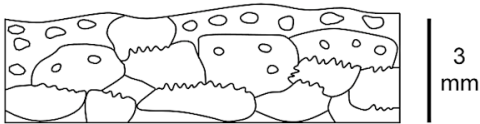

FIG. 6. Drawings of some crystalline textures present in the borax laminae of the laminated borax lithofacies. Grey areas (in D to G) correspond to the lutitic matrix. (A) Palisade fabric. The borax crystals show zoned growth (matrix inclusions) at the top. (B) Palisade fabric. The borax crystals show zoned growth (matrix inclusions) and poikilitically enclose some microcrystals of borax at the top. (C) Transparent, unoriented texture. Borax crystals are rectangular to equant. (D) Matrix-rich, unoriented texture. The borax crystals within the matrix are euhedral to subhedral, with zoned growth. (E) Clastic texture, with very variable size of crystals. Large crystals are slightly rounded, may have a zoned growth, and display an orientation that is roughly parallel to bedding. (F) Mixed texture. Palisade fabric at the base and smaller crystals of borax at the top. The truncation surfaces at the upper part of the crystals forming the palisade fabric suggest dissolution. (G) Mixed texture. At the base of the lamina, euhedral, zoned crystals of borax predominate. These crystals have variable size and are surrounded by an abundant lutitic matrix. At the top of the lamina, a palisade fabric is developed. $(\mathrm{H})$ Mixed texture. Platy to tabular crystals of borax at the base predominate. Smaller crystals of borax predominate at the top of the laminae, suggesting either graded bedding or bimodality. (I) Transparent, imbricated texture. The imbrication can be the result of a mechanical, smooth deformation; commonly, the crystal boundaries are sutured. (J) Sutured texture of the borax crystals. 


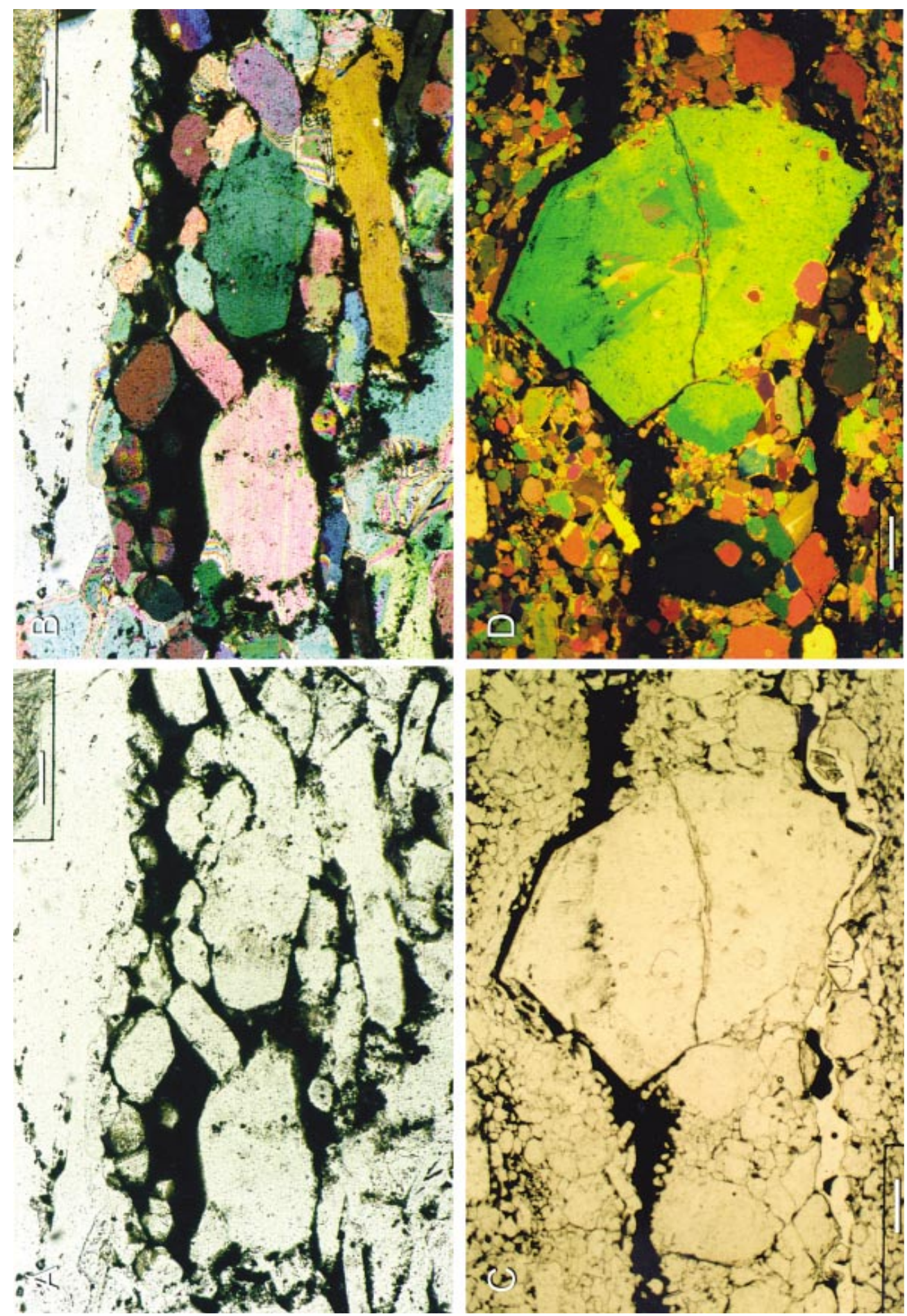

FIG. 7. Borax textures and fabrics under the microscope. (A) and (B) Platy to tabular textures of the borax crystals. Normal light (A) and crossed nicols (B). Scale bar: $0.32 \mathrm{~mm}$. (C) and (D) Detail of a palisade fabric with a borax crystals in subvertica orientation surrounded by smaller crystals of borax. Normal light (C) and crossed nicols (D). Scale bar: $0.64 \mathrm{~mm}$. 


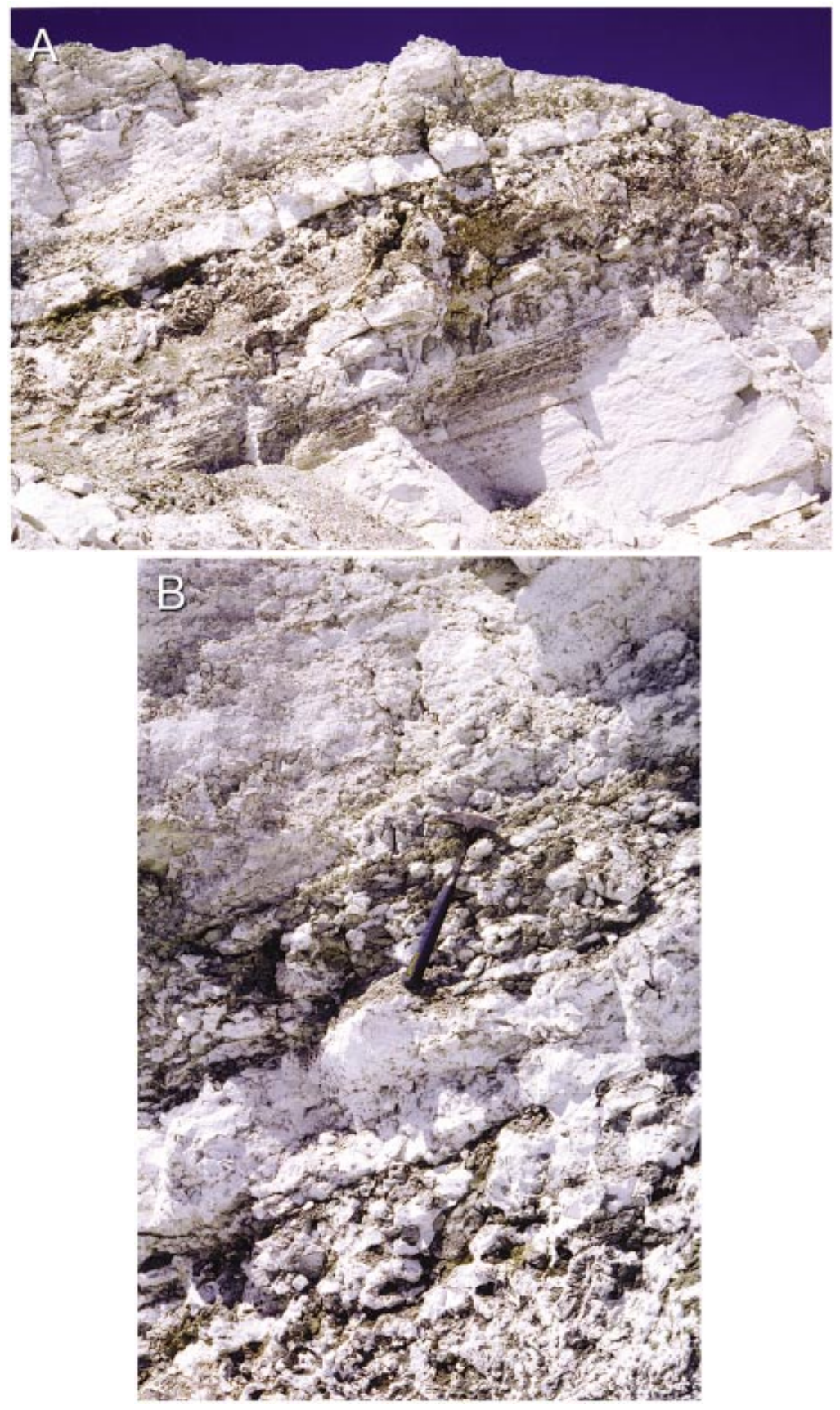

FIG. 8. A. Macrocrystalline interstitial borax lithofacies. View of layer B (central part of the picture) in the Kırka open-pit mine (Section 2). The top of layer A (lower part of the picture) and the base of layer $\mathrm{C}$ (upper part of the picture) can be also observed. Hammer for scale. B. Macrocrystalline interstitial borax, layer B. The picture shows an alternation between inconsistent matrix-rich layers with individualized crystals and patches of crystals of borax, and cohesive, matrix-poor layers with predominant macrocrystalline interstitial borax. Dark material is clayey to marly matrix; clear material consists of borax crystals with the surface altered to tincalconite. Hammer for scale. 


\section{Crystalline massive borax}

This lithofacies (layer C) consists of transparent, subhedral to anhedral, interlocking crystals ranging from $<1$ to $2 \mathrm{~cm}$ in length (Fig. 9). In some crystals, a poorly developed zonal pattern is observed under the microscope. The crystal fabric is unoriented, densely packed, and free of lutitic matrix. Locally, small patches of lutitic matrix and crystalline masses with a geodic or recrystallized appearance (clusters of coarser, brownish crystals) are present. The contact between this lithofacies and the overlying laminated borax (layer D) is gradational to sharp, and concordant.

\section{Borax veins and other secondary features}

Veins several $\mathrm{cm}$ thick, which cross-cut the borax deposit randomly, were observed, in particular in asso-

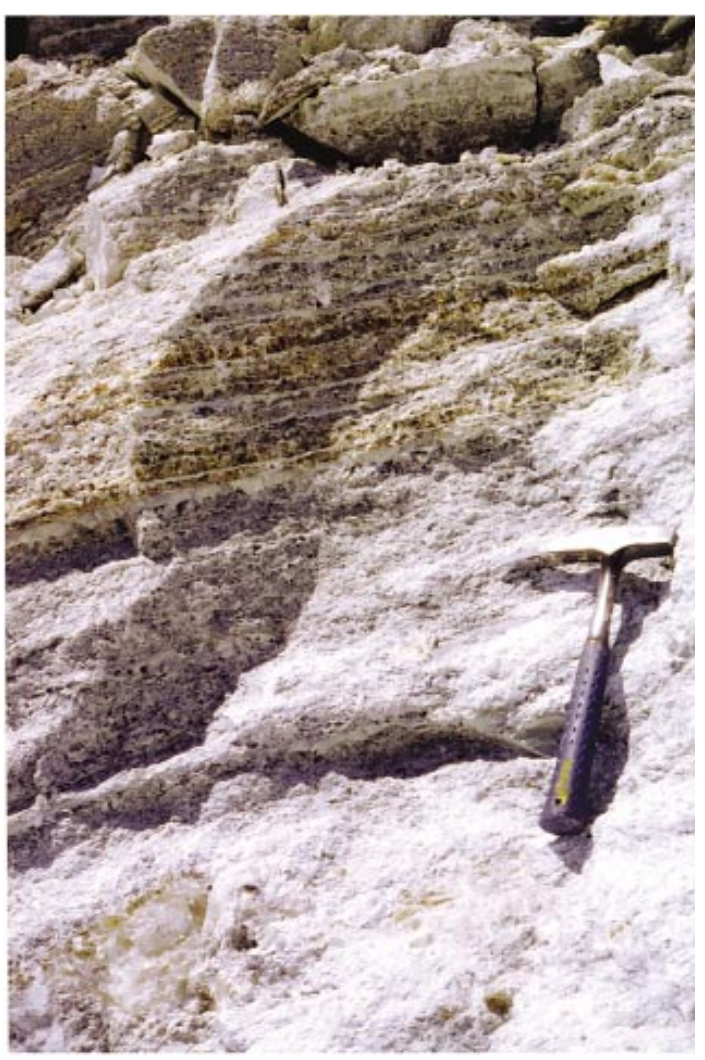

FIG. 9. Massive crystalline borax lithofacies. Boundary between the massive crystals of borax of layer C (lower part of the picture), and the laminated borax of layer D (upper part of the picture). Note the gradational contact (central part of the picture), where a palisade fabric is developed. In layer $\mathrm{C}$, local areas with a recrystallized appearance are distinguished. Clear laminae are made up of the lutitic matrix. ciation with the macrocrystalline interstitial lithofacies (layer B). Inan et al. (1973) described other features of the borax related to secondary processes, such as vugfilling borax or borax-clay breccias. At or near the surface, many crystals of borax display films of alteration to tincalconite because of partial dehydration. The sparse presence of kernite crystals in this deposit suggests that the alteration of the borax crystals to kernite, which is a common process in other Neogene borax deposits, was limited at Kirka.

Recrystallized borax is present in portions of the open-pit mine and in former underground mines. It consists of pure masses of borax of irregular geometry that are not concordant with stratification. These masses are commonly linked to deformed beds of borax.

\section{Interpretation of the borax lithofacies}

Several textures of the laminated borax lithofacies are similar to the primary textures recorded in halite deposits, and correspond to subaqueous precipitation on a lake floor. Other textures represent reworking in the same subaqueous setting over relatively short distances. The palisade fabric implies a competitive growth of crystals on a depositional surface. The truncated geometry at the top of some crystals reflects dilution of the water body and associated dissolution of crystals. The transparent, unoriented texture, characterized by euhedral to subhedral crystals displaying normal grading without any evidence of transport, suggests noncompetitive growth and precipitation on a lake bottom under conditions of progressive oversaturation. The matrix-rich, unoriented texture represents non-competitive growth within a muddy lake-bottom, where abundant clay-sized matrix is supplied. The clastic texture represents conditions of reworking in the lake and, presumably, transport of crystals from the margins to the center of deposition. No clear criteria exist for deciphering if some of these clastic laminae were formed by local turbidity currents, as observed by Bowser (1965) in the Kramer deposit of California. In the mixed textures, the upward gradation from a palisade fabric to a transparent unoriented texture represents changing conditions in the water mass of the lake, which resulted in gradations from slow to rapid precipitation. Also, changing conditions represents the upward gradation from a palisade to a clastic texture.

Under the microscope, the platy to tabular texture, with elongate crystals parallel to bedding, represents cumulates that sank from the air-brine interface. Similar platy hopper crystals are known as halite cumulates (the "bacilar hoppers" of Pueyo (1975); the "elongate crystals of cloudy halite" of Rosell \& Ortí 1981-82). The imbricated-like fabric could better be linked to some mechanism of deformation (or compaction) than to a hydrodynamic control of crystal growth. The $s u$ tured texture is a typical feature of pressure solution of crystals. 
The zoned pattern exhibited by many laminae, characterized by either a transparent or a matrix-rich unoriented texture, indicates non-competitive subaqueous growth on a lake bottom or within the bottom muds, respectively. The small crystals of borax entrapped at the top of many large crystals forming the palisade fabric suggest a combination of environmental growths, on the bottom (large crystals) and in the water mass (small crystals). The small crystals are poikilitically enclosed by the large ones, after settling from the air-brine interface.

Although evaporative concentration was the major factor leading to the precipitation of borax, a significant control on this crystallization could have been exerted by thermal changes (brine cooling). Bowser (1965) discussed that possibility in the Kramer deposit, and carried out laboratory experiments justifying his interpretation by precipitating borax laminae with reverse grading with a palisade fabric at the top. Bowser (1965) also observed the zoned pattern in many crystals of borax in the Kramer deposit and was able to count in them about forty inframillimetric zones consisting of an alternation between matrix films and borax bands; this growth pattern was interpreted as a daily control on borax solubility (night cooling and associated crystallization).

The interpretation of the macrocrystalline interstitial borax lithofacies, which is characterized by large crystals embedded in lutitic matrix, can be made by comparison with modern occurrences of borax in playa lakes and salars. In these exposed settings, large, euhedral crystals (centimetric, up to $10-20 \mathrm{~cm}$ in length) of either transparent or zoned (inclusion-rich) borax develop displacively within the soft sedimentary matrix. The growth is mainly controlled by the underground position of the water table and occurs at the top of the phreatic zone and in the vadose-capillary zone (Alonso 1986). This setting is presumably valid for the Kırka deposit also, despite the fact that evidence of exposure (desiccation cracks) in Section 2 is limited. In the Boron deposit, where several layers of this borax lithofacies also are present, Swihart et al. (1996) suggested crystallization under conditions of partial desiccation despite both the absence of desiccation cracks and the subaqueous environment interpreted for this lithofacies in previous papers (Bowser 1965, Bowser \& Dickson 1966).

The crystalline massive borax lithofacies, which is characterized by the absence of both internal bedding and a lutitic matrix, has an uncertain origin. This lithofacies could correspond to: (1) generalized recrystallization, (2) interstitial growth under synsedimentary conditions in an exposed playa-lake setting, and (3) primary, subaqueous crystallization of borax. Inan et al. (1973) described masses of borax characterized by unoriented crystals and crystal faces with $120^{\circ}$ angles in the Kurka deposit as evidence of burial recrystallization. In Section 2, however, the contact between this lithofacies and the overlying laminated borax is con- formable. It seems unlikely that the interstitial growth of the borax crystals can almost completely eliminate the lutitic matrix, to result in a texture totally different from the cohesive, matrix-poor, macrocrystalline interstitial borax of layer B (Fig. 9). In contrast, it seems likely that a massive precipitation on a relatively deep lake floor, protected from matrix and clastic supplies, led to such a pure, interlocking crystalline texture. The third interpretation is tentatively proposed in this paper because similar transparent, coarsely crystalline textures have been cited by Last (1994) in the modern precipitates of mirabilite of some deep evaporitic lakes in Canada, where mirabilite forms under low-temperature conditions.

Borax cross-cutting veins result from the cementation of fractures and planes of discontinuity. The masses of recrystallized borax correspond to dissolutionreprecipitation caused by circulating groundwater along fractures and other deformation-related features.

\section{The Calcium-Bearing Borates}

\section{Ulexite}

The main occurrence of ulexite in Section 2 is the columnar to massive lithofacies in layer $\mathrm{E}$, which is 1.5 to $2 \mathrm{~m}$ thick (Fig. 10A). This lithofacies consists of structureless to nodular masses with a subvertical elongation, in which ulexite is characterized by a fine, fibrous texture (Fig. 10B). The content of lutitic matrix disseminated in this layer is very low. In other parts of the Kirka deposit, the ulexite is composed of cauliflower-like nodules surrounded by a higher proportion of clay matrix, where it forms layers up to a few meters thick (Inan et al. 1973). Some veins of fibrous ulexite were observed cross-cutting layer E.

In layer $\mathrm{D}$, some ulexite is present as lenticular or disc-shaped nodules (a few $\mathrm{cm}$ in diameter) associated with borax. These nodules, semilenticular in geometry also, are composed of fibers and prismatic crystals oriented normally to the borax laminae (Fig. 10C). Near the contact with these ulexite features, the borax laminae thin out. Under the microscope, the ulexite fibers replace the borax crystals (Fig. 10D), and the ulexite nodules contain abundant pseudomorphs after borax (Figs. 10E, F). These features of ulexite are also associated with thin $(<1 \mathrm{~cm}$ wide) veins of fibrous ulexite, which may be single or double; in the latter case, the two veins intersect at about $90^{\circ}$ (Fig. 10G). A view of these nodules on a bedding surface is shown in Figure $10 \mathrm{H}$.

\section{Interpretation}

The columnar to massive ulexite exhibits no clear evidence of subaqueous precipitation, although this possibility cannot be disregarded. Such a lithofacies, which laterally grades to cauliflower-like nodules surrounded 

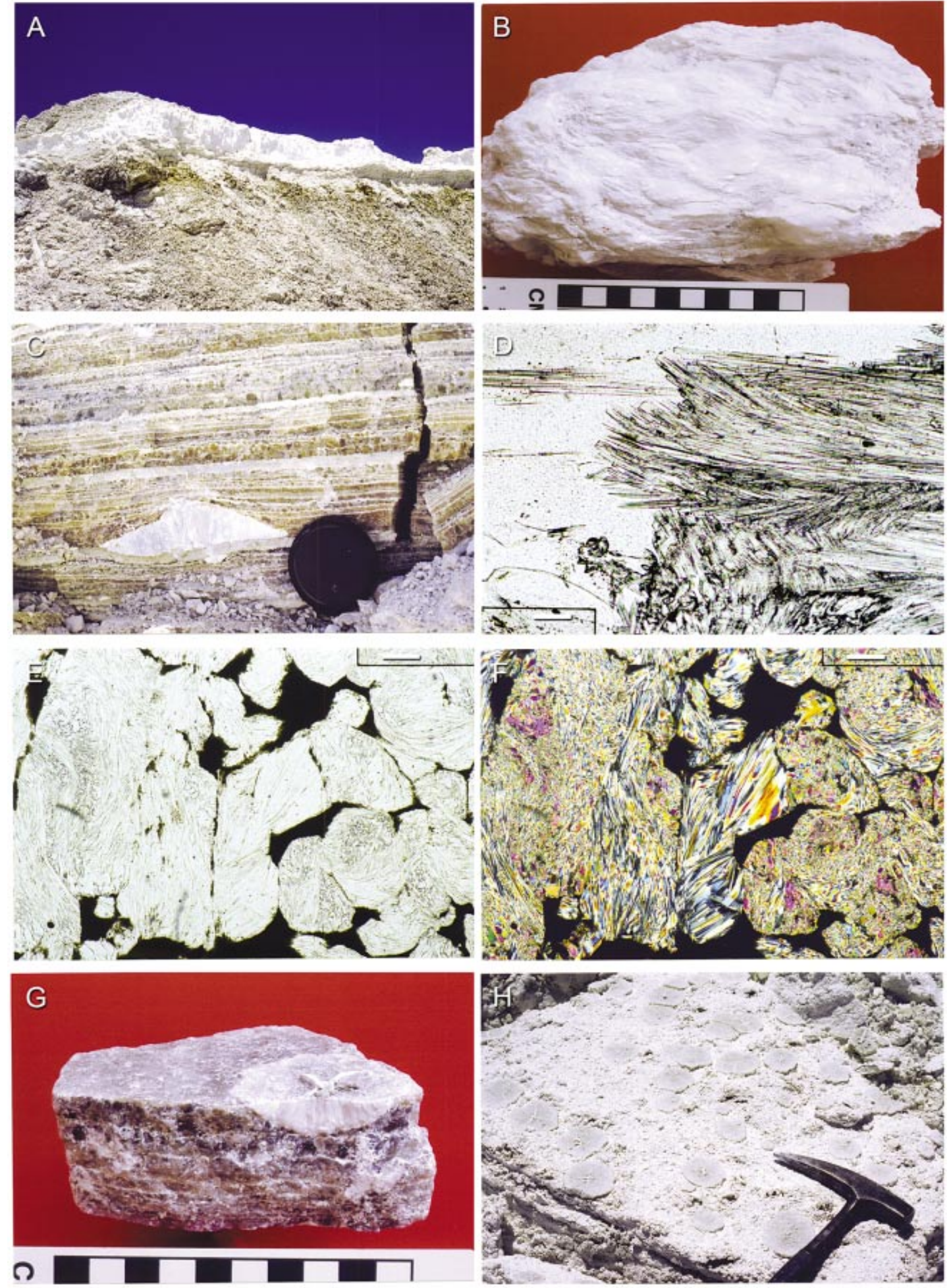
by abundant matrix, can preferentially form on a shallow lake bottom or grow displacively under exposed conditions (playa lake). This second possibility seems more likely on the basis of modern occurrences of interstitial ulexite (cotton-ball nodules, nodular to columnar masses) in playas and salars (Bowser 1965, Muessig 1966, Alonso 1986, Helvac1 \& Alonso 2000).

The lenticular nodules of ulexite in layer $\mathrm{D}$, which are developed within the laminated borax, display geometrical relationships suggesting a syndepositional interaction between the growth of ulexite and the accumulation of borax crystals. These nodules developed synchronously with the laminae by the reaction of those crystals with the interstitial Ca-bearing boratiferous brines. The growth of ulexite started along planes of permeability (bedding surfaces, small fractures, incipient cracks in the lutite laminae) and progressed against the borax laminae (replacing the crystals) and within the lutite laminae (cementing the fractures). Such growth of ulexite happened during very early diagenesis, when the borax laminae were still being deposited and the lutite laminae remained unlithified.

\section{Colemanite}

In layer $\mathrm{F}$, colemanite exhibits three main lithofacies: nodular, massive brecciated, and massive. Nodular colemanite consists of almost spherical masses up to several decimeters in diameter $(<10 \mathrm{~cm}$, in general $)$

FIG. 10. Ulexite lithofacies and microstructures. (A) View of ulexite layer E, overlying the borax body. The predominant lithofacies is columnar to massive, with very little matrix. The maximum thickness of this layer is about $2 \mathrm{~m}$. (B) Close-up view of a sample of columnar to massive lithofacies. Scale in $\mathrm{cm}$. (C) Laminated borax in layer D displaying a syndepositional, lenticular-shaped nodule of ulexite. The inner fabric of this nodule is fibrous and subvertical. Toward the top of the nodule the surrounding laminae of borax thin out. The lutitic laminae underlying the nodule are deformed by the growth of the nodule (or by some degree of compaction). The palisade fabric can be observed in several borax laminae overlying the ulexite nodule. Diameter of the lens cap: $6 \mathrm{~cm}$. (D) Detail of ulexite fibers (on the left) replacing a borax crystal (on the right). Photomicrograph; normal light. Scale bar: $0.08 \mathrm{~mm}$. (E) and (F) Detail of the contact between a nodule of ulexite (similar to the nodule in D) and a borax lamina; the ulexite has replaced the borax crystals, preserving the shapes (ulexite pseudomorph after precursor borax). The dark material corresponds to the lutitic matrix. Photomicrograph; E: normal light; F: crossed nicols. Scale bar: $0.32 \mathrm{~mm}$. (G) Detail of a semilenticular nodule of ulexite growing within a borax lamina. In the central part of the nodule, two veins of fibrous ulexite (crossing at $90^{\circ}$ ) can be observed. (H) Top view of a borax layer displaying lenticular nodule of ulexite.
(Fig. 11A) composed of elongate, prismatic to fibrous crystals that may display a radiating fabric from the center outward. Septaria-like fractures, geodic structures, and hollow centers are found in some nodules. Massive to brecciated colemanite consists of crystalline masses acting as a cement of disrupted blocks of carbonate, or clay-rich parts of layer F. Massive colemanite consists of dense, stratiform masses in which vug porosity is common; geodic areas are irregularly distributed in these stratiform masses (Fig. 11B). A few veins of fibrous colemanite were locally observed in layer $\mathrm{F}$.

\section{Interpretation}

The various lithofacies of colemanite exhibit complex characteristics (nodules, breccia-cement and irregular stratiform masses) that are similar to other Miocene borate deposits in Turkey. In the opinion of Inan et al. (1973), colemanite in the Kırka deposit is a result of either the alteration of ulexite to colemanite, or the transformation of an inyoite precursor to colemanite. Regarding the first possibility, Inan et al. (1973) found evidence of this transformation at various stages in some parts of the Kurka deposit. Such a transformation, however, was not observed by us in Section 2. Regarding the second possibility, Inan et al. (1973) deduced that the septarian nodules and cracks in the geodes are the result of a volume change that took place during the inyoite-to-colemanite transformation. Regarding this inference, (1) there is no petrographic evidence for such a generalized process, and (2) the estimated maximum depth of burial in this deposit is only moderate (about $300 \mathrm{~m}$ ) and not sufficient for this transformation. In the Neogene Furnace Creek Formation, Death Valley, California, Smith \& Medrano (1996) calculated a minimum depth of burial of $1100 \mathrm{~m}$ for the meyerhofferite-to-colemanite transformation (at approximately $32^{\circ} \mathrm{C}$ ). Helvacı \& Ortí (1998) argued that in the geological context of western Turkey, the burial undergone by the Neogene borate deposits was insufficient for the drastic inyoite (or meyerhofferite)-to-colemanite transformation by thermal diagenesis. This reasoning seems to be particularly valid for Kırka, where the extent of the borax-to-kernite transformation is limited, in contrast to the Kramer deposit of California, where this transformation has been well documented (Barnard \& Kistler 1966). Other authors have interpreted the colemanite nodules as being primary (Bowser \& Dickson 1966, Helvaci \& Firman 1976, Barker \& Barker 1985, Alonso et al. 1988, Helvaci 1984, 1995, Palmer \& Helvaci 1995).

\section{Other borates of $\mathrm{Ca}$}

Inyoite was found in Section 2 as sparse, discrete crystalline masses scattered in layer F, in particular toward the top. Meyerhofferite was not found in this section, although it is present in the Kirka deposit as 

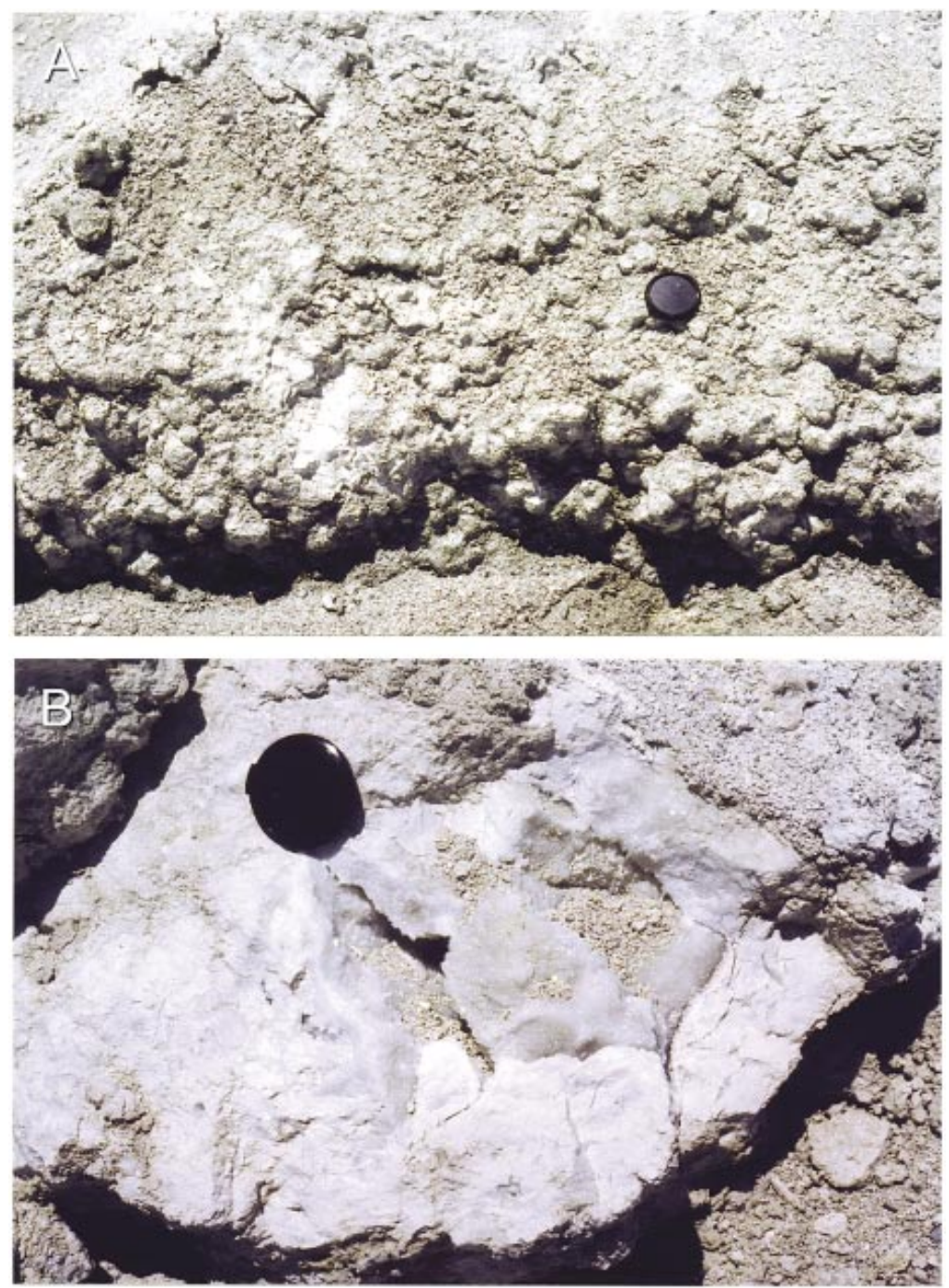

FIG. 11. Colemanite lithofacies. (A) Nodular lithofacies of colemanite in layer F. Average diameter of the nodules is close to $5 \mathrm{~cm}$. Diameter of the lens cap: $6 \mathrm{~cm}$. (B) Massive colemanite lithofacies in layer F. Crystalline masses, vug porosity, geodic areas and cemented fractures can be observed. Diameter of the lens cap: $6 \mathrm{~cm}$.

microscopic crystals (Inan et al. 1973). Priceite is present as small nodules (1-2 cm in diameter) in the claystone beds overlying the borax body (Çolak 1995, Helvacı \& Alonso 2000).

\section{Mg-Bearing and SR-Bearing Borates}

Kurnakovite and, to a lesser extent, inderite, are present in ulexite $\mathrm{E}$ and in the claystone bed underlying layer $\mathrm{E}$, as discontinuous, irregular, transparent masses of fine to coarse crystals (1-2 cm long) that displace the surrounding clay matrix. Locally, these masses are associated with spherulites and small nodules of ulexite (Fig. 12A). The textures of kurnakovite vary from euhedral to subhedral, and display a blocky to mosaic appearance (Fig. 12B). In the ulexite-kurnakovite association, the ulexite fibers seem to replace the kurnakovite crystals (Fig. 12C).

Hydroboracite nodules, up to 1 decimeter in diameter, are associated with colemanite in layer F. These 


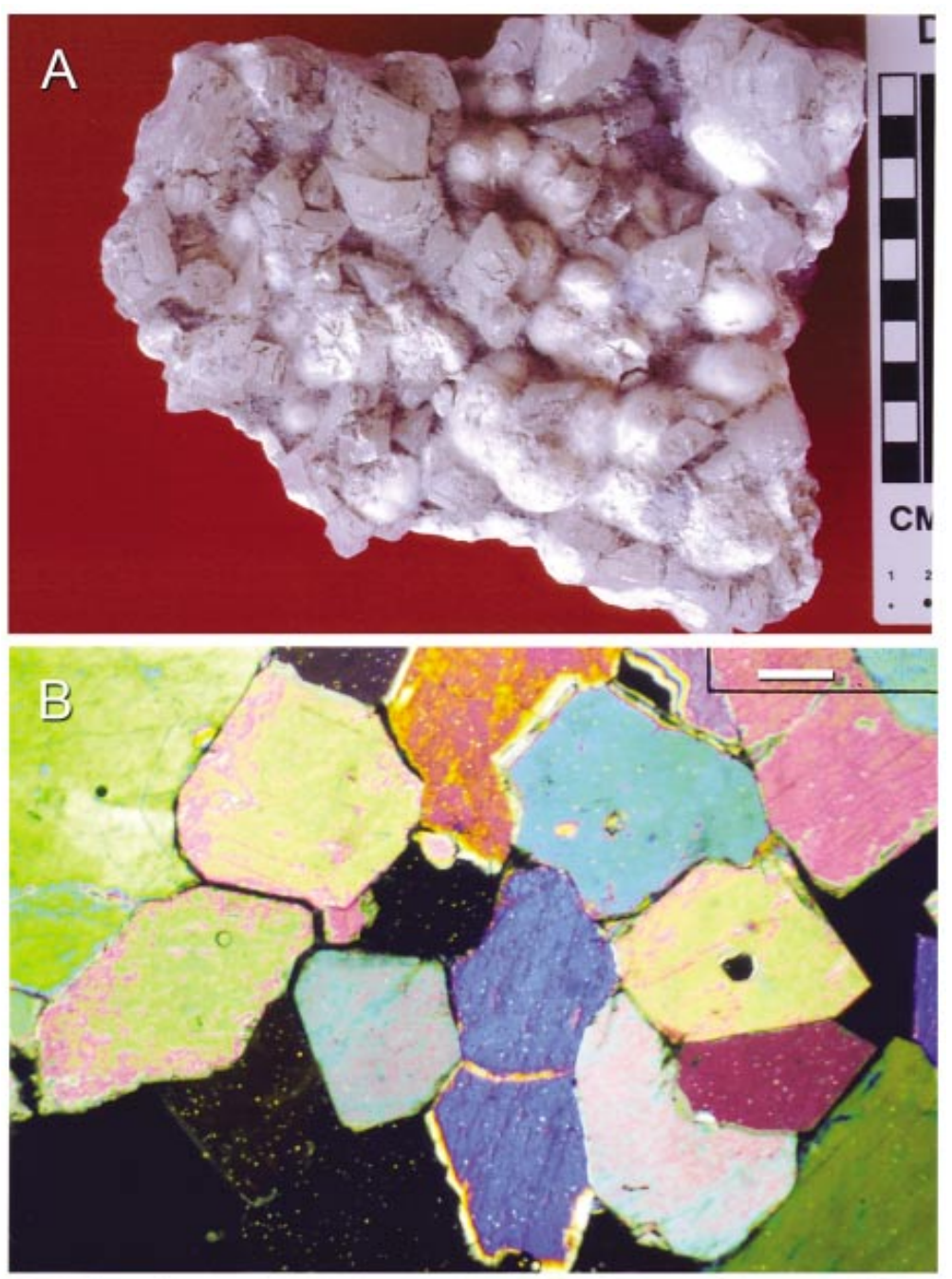

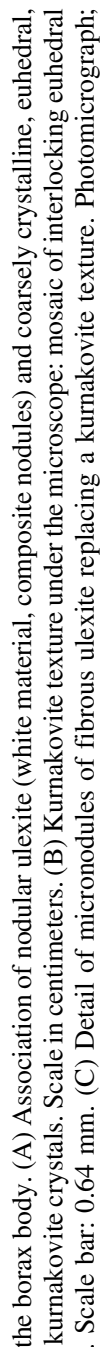

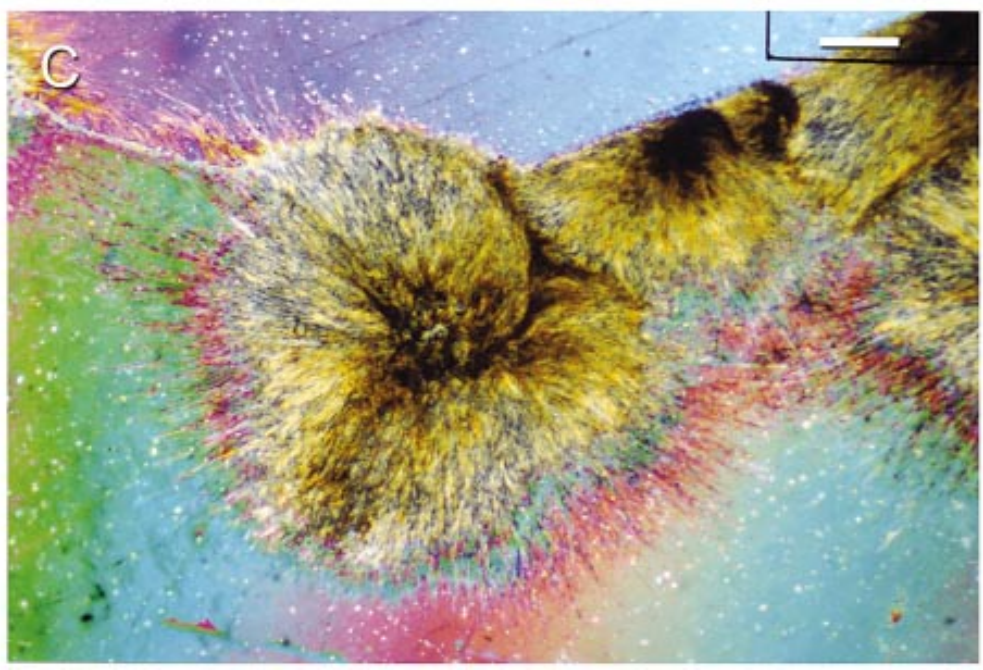

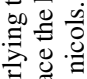

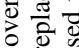

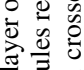

要

은

응

政

政。

을

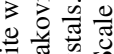

要

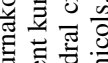

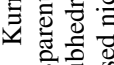

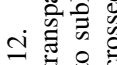

完 
nodules are composed of fibers and prismatic crystals, either straight or slightly curved, that display variable orientations (Fig. 13). An intercrystalline clay matrix is common. These characteristics are also similar to the fibrous texture in the hydroboracite deposit of the Sijes Formation in northwestern Argentina (Helvac1 \& Firman 1976, Helvac1 1984, 1995, Ortí \& Alonso 2000).

Tunellite in dispersed crystals and crystalline masses is associated with ulexite in layer $\mathrm{E}$ and within clay in the claystone bed underlying this layer. The tunellite crystals are euhedral to subhedral, 1 to $3 \mathrm{~cm}$ in size, and characterized by one perfect cleavage. Some microcrystalline masses display a prismatic to blocky-mosaic texture (Fig. 14).

\section{Interpretation}

The presence of borates of $\mathrm{Mg}$ overlying the borax layer D has been interpreted by Inan et al. (1973) as a product of reaction between primary borates and $\mathrm{Mg}$ enriched solutions. The same interpretation was made by Smith \& Medrano (1996) for the borates of Mg associated with Neogene Na- and Ca-borate deposits in general. However, Crowley (1996) has suggested that the $\mathrm{Mg}$ borates and $\mathrm{Mg}$-bearing borates reported as accessory minerals in these Tertiary lacustrine deposits can represent end products of evaporative fractionation. This fractionation occurs along a succession of chemical divides, during which the precipitation of borate itself plays an important role. The fact that $\mathrm{Mg}$ and $\mathrm{Ca}-\mathrm{Mg}$ borates could be products of end-stage fractionation also suggests that their distribution with respect to $\mathrm{Na}-\mathrm{Ca}$ ore minerals is likely to be zoned. In this view, the $\mathrm{Mg}$ bearing borates overlying the borax layer D in Kırka could reflect precipitation from interstitial brines at the end of their evolution. These residual brines would mix with Ca-rich boratiferous solutions during the final playa-lake stage of the lacustrine system in Kırka. The fact that: (1) no pseudomorphs of kurnakovite after a borate precursor were found, and (2) the borates of $\mathrm{Mg}$ are located only at the top of the borax body, seems to support such an interpretation. Other Neogene examples are known where Mg-bearing borates precipitated subsequently to the formation of $\mathrm{Ca}$ and $\mathrm{Na}$ borates. Thus, hydroboracite formed extensively in the Miocene Sijes Formation of northwestern Argentina after the precipitation of gypsum and colemanite (Ortí \& Alonso 2000).

\section{The Borax Sequence}

Inan et al. (1973) recognized in the Kurka deposit a single depositional sequence (a large-scale, "gross phase zoning"), and two types of microcycles ("oscillatory phase zoning") of borax-ulexite and ulexite-inyoite. These microcycles, however, were not identified by us in Section 2.

The origin of the Kurka borax sequence in Section 2 can be understood on the basis of some "key" borate lithofacies that have been interpreted above: (1) the nodular and massive ulexite-colemanite mainly represent interstitial growths within the clayey-dolomitic matrix in very shallow to exposed settings; (2) similar settings as in (1) apply to the macrocrystalline interstitial borax; (3) the massive crystals of borax of layer C represent a relatively deep-water precipitate, instead of a product of recrystallization, and (4) the Mg-bearing borates at the top of the sequence correspond to precipitates from residual, evolved brines.

Thus the Kirka borax deposit is viewed as an evaporite sequence in which a lower cycle can be differentiated from an upper cycle (Fig. 4). The lower cycle (I) comprises the (unexposed) colemanite and ulexite layers at the base of the sequence, and the overlying borax layers A and B. Although descriptions of specific lithofacies of these ulexite and colemanite layers are not available, it is likely that their characteristics are similar to those observed in the layers at the top of the sequence; they seem to have formed in shallow water or in underground positions of the brine during an initial playa-lake stage. Subsequently, the brine became free (subaerial) during a stage of perennial lake, leading to borax precipitation as the thick layer A. In this lake, both chemical and clastic borax laminae accumulated, and the thickness of the borax-lutite couplet commonly oscillated from $<1$ to $5 \mathrm{~cm}$. Presumably, transport was not very important in this lake, given that large-scale structures suggestive of strong movement were not observed. Also, borax beds of possible turbiditic origin and slumping features were not identified. The precipitation of borax on the lake floor was favored by periodic cooling of the brine. These facts suggest that the lake was not very deep, probably ranging between some meters and a few tens of meters. Based on this reasoning, Bowser (1965) already proposed a maximum depth of about 20 $m$ for the borax-depositing lake of the Kramer deposit. In the Kirka sequence, some brief periods of subaerial exposure, based on the presence of rare mudcracks, cannot be ruled out. The cycle finished with a drop in water level to an underground position, which resulted in the interstitial growth of large, displacive borax crystals (layer B). As a whole, this cycle (1) represents the development of a body of boratiferous water and its evolution from a calcic to a sodic-calcic, and a final sodic character, and (2) begins and ends with shallow to exposed settings.

The upper cycle (II) starts with the accumulation of borax layer $\mathrm{C}$, which is tentatively ascribed to a relatively deep lacustrine setting, unaffected by changes in surface temperature, and characterized by a slow rate of precipitation; this interpretation implies the re-appearance of the lake (flooding). Subsequently to this stage, the lake would have become shallower and a recurrent, temperature-controlled borax lithofacies formed; this is the laminated layer D. This lithofacies, however, differs somewhat from that in layer A: (1) the borax laminae are thinner and richer in clay matrix, and the 
borax-lutite couplet is also thinner (it oscillates between $<1$ and $2 \mathrm{~cm}$ ); (2) the clastic textures are absent, and (3) the borax is slightly replaced by small, lenticular nodules of ulexite. For the laminated borax of layer D, all these features suggest (1) a shallower setting than in layer A, and (2) a Ca content in the interstitial brine of the borax sediment higher than in layers A to C, so backreactions between the pore brine and the borax crystals resulted in limited borax-to-ulexite alteration under synsedimentary conditions. This second stage of the perennial lake ended (at the top of layer D) with the accumulation of a claystone bed followed by ulexite layer $\mathrm{E}$. The discontinuous occurrence of $\mathrm{Mg}$ borates in the claystone bed is interpreted as an interstitial, mineralogically primary precipitation of borate derived from complete fractionation of an evolved brine, and it is likely that the occurrences of tunellite (associated with the claystone bed and the ulexite layer E) and hydroboracite (associated with colemanite in layer F) have the same origin. The precipitation of both the $\mathrm{Mg}$ borates and layers $\mathrm{E}$ and $\mathrm{F}$ is considered to have occurred in playa-lake settings from a boratiferous brine progressively enriched in Ca. Thus, this upper cycle (II) reflects brine dilution: from a sodic and subsequently magnesian character, to a sodic-calcic character first, and to a calcic character at the end. It also reflects, from the viewpoint of lake subenvironments, a shallowing upward trend.

\section{ORIGINS OF THE ZONATION IN the Neogene Borate Deposits}

The best-known lacustrine bodies from which borax is currently precipitating are modern playas and salars, where large euhedral crystals of this mineral are found disseminated within unconsolidated mud (Bowser 1965, Muessig 1966, Alonso 1986, Kistler \& Helvac1 1994). Also, borax crystallization in modern deep lakes has been cited by Sun \& Li (1993) in the Tibet Plateau, but detailed descriptions of such occurrences to be compared with the ancient formations are not available. As a result, no general agreement exists concerning the interpretation of the mineral zonation found in the Neogene borate deposits.

Basically, three genetic mechanisms have been proposed in the literature for the mineral zonation of the ancient borate formations (Smith 1985, Smith \& Medrano 1996, Helvacı \& Ortí 1998, Ortí \& Alonso 2000): (1) an evaporitic primary mechanism, (2) early reaction diagenesis, and (3) late reaction diagenesis. The evaporitic primary mechanism involves the evaporative control of the lacustrine depositional system, the existence of a lateral gradient of salinity, and the direct precipitation of each mineral zone from brines of the appropriate chemical composition. This precipitation can happen both in a body of free brine (subaqueously) and within pre-existing muds (interstitially). These zones could be considered as "evaporitic-primary zones".

In the early reaction diagenesis, the mineral zones surrounding the central body of borax are caused by the reaction of Ca-rich groundwater seeping into the lake either with (a) the borax crystals of the central body, or (b) the Na-borate-bearing interstitial brines in the muds surrounding the lake. The reaction can occur at different times: under synsedimentary conditions, during initial burial, during moderate burial, or during deep burial. Case (a) results in "secondary zones", because a precursor mineral (borax) is replaced by a secondary one (a Ca-bearing borate). Case (b), however, results in "chemical-primary zones", because the mixing mechanism leading to a mineralogically primary precipitation is considered to be a simple chemical process, in which the existence of evaporation or lateral gradients of concentration are not needed (Bowser 1965). In this view, the chemical-primary zones can form from synsedimentary to moderate burial conditions, but always before the final lithification of the sediment (Barnard \& Kistler 1966).

In the late reaction diagenesis, the zonation is caused by the reaction of Ca-rich groundwaters with the preexisting borate minerals during the final uplift (exhumation) of the borate unit (Smith 1985, Smith \& Medrano 1996). In general, there is agreement in the literature that this mechanism can account for the presence at the top of the deposits of a number of features: cross-cutting veins of several borate minerals, irregular crystalline masses of replacive borates, and pseudomorphs of more hydrated (or more soluble) borates after less hydrated (or less soluble) borates. However, two main objections can be made to this type of diagenesis as being the major mechanism responsible for the mineral zonation in the deposits: (1) the difficulty in producing an almost perfect, symmetrical (in all directions) envelope composed of successive replacive zones by the simple action of groundwater on a borate unit, and (2) the fact that the zones formed by such a process would very likely have an irregular geometry. In contrast, the mineral zones in the ancient borate deposits are individualized, and well separated from each other and from the central body of borax by conformable (stratigraphic) contacts (Barnard \& Kistler 1966). Moreover, no mixed or transitional zones are found in which both the precursor borate and the secondary borate coexist.

An example of the application of these genetic mechanisms to the zoned borate deposits of Neogene age is that of Kramer, the best known borax deposit in the world. The Kramer borate deposit, at Boron, California, is a lenticular mass of borax and interbedded clays with a thickness of about $100 \mathrm{~m}$. The deposit has a Miocene age and exhibits a zonal structure, and in its lower part the borax has been largely replaced by kernite (Kistler \& Helvac1 1994). Barnard \& Kistler (1966) distinguished the following sequence from base to top: 
barren facies, ulexite facies, sodium borate facies, ulexite facies, colemanite facies, and barren facies. In the sodium borate facies, these authors also differentiated between several high-grade ( $>75 \%$ borax) borax units of economic interest (upper, middle, lower and basal ore) and some low-grade ( $<60 \%$ borax) borax units (A, B, C). Bowser (1965) distinguished three main borax lithofacies, all deposited in a lake setting: (1) thinly bedded borax, the most important of them, which was assigned to primary precipitation linked to thermal variation in the water mass; this lithofacies is equivalent to the laminated borax in the Kurka deposit; (2) massive borax, which was ascribed to borax resedimentation in the lake, and (3) large, isolated subhedral crystals of borax, sparsely distributed in massive claystone beds, which was ascribed to interstitial growth. This lithofacies, which corresponds to the low-grade borax units of Barnard \& Kistler (1966), is similar to the macrocrystalline borax in Kirka.

The most relevant aspects of the various interpretations of the zoned Kramer deposit are summarized in Figure 15. Smith (1960) first proposed a deep lake setting for the precipitation of borax in this deposit. Bowser (1965) postulated that this precipitation occurred in a perennial shallow lake ( $<20 \mathrm{~m}$ deep) from a homogeneous Na-borate brine under the control of both evaporation and temperature changes in the water mass (Fig. 15A). According to Bowser (1965), the sequence of borax accumulated without significant variation in boron content, and invariably in subaqueous conditions. The external mineral zones are also primary and derived from synsedimentary mixing of interstitial solutions without any influence of evaporation or lateral gradients of concentration (chemical-primary zones). The crystallization of borates in these zones only began once borax saturation in the lake was achieved (a synchronous process).

Bowser \& Dickson (1966) also considered the "early chemical zonation" in the Kramer deposit as primary, but introduced a number of new interpretations: (1) the mineral zonation could have occurred by subsurface reaction of groundwater not only with Na-borate-rich brines entrapped in the muds of the lake margins (chemical-primary zones), but also with the Na-borate minerals of the central body (secondary zones); (2) the ulexite and colemanite zones could have formed also by either cation exchange with a smectite-group mineral, or from interstitial brines of an appropriate composition (chemi-

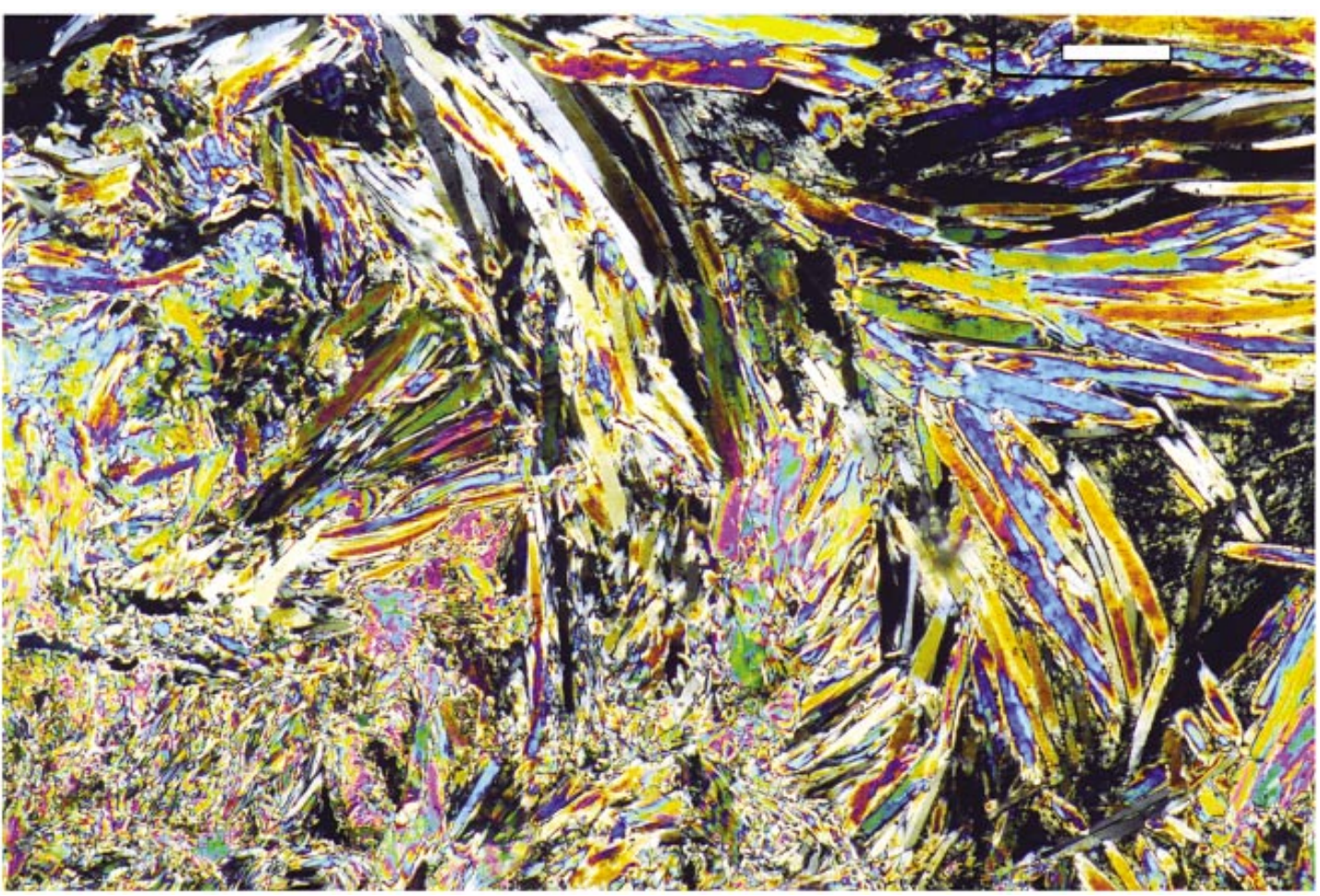

FIG. 13. Petrography of a nodule of hydroboracite associated with colemanite in layer F. Prisms and fibers of hydroboracite are arranged in unoriented spindles (bundles). Intercrystalline material is a clayey matrix. Photomicrographs; crossed nicols. Scale bar: $0.32 \mathrm{~mm}$. 
cal-primary zones), and (3) part of the colemanite lithofacies (the septarian nodules) is a primary precipitate (chemical-primary zone).

Barnard \& Kistler (1966) proposed a shallow permanent lake for the precipitation of borax at Kramer, which was controlled by temperature changes in the water mass (Fig. 15B). The crystallization of borax was invariably subaqueous, but the boron concentration decreased during the formation of the low-grade borax zones (A, B, C). The ulexite zone, however, formed as a synsedimentary deposit in a playa lake as a lateral facies change; this ulexite precipitated by mixing Ca-rich groundwater with the Na-borate brine surrounding the borax lake (chemical-primary zone). The colemanite, however, could have been derived by the transformation of ulexite by groundwater acting during initial or late burial diagenesis (secondary zone). After the destruction of the permanent borax lake, the ulexite zone overlying the borax body was again deposited in a playalake setting.

Swihart et al. (1996) studied the isotopic composition $\left(\delta^{11} \mathrm{~B}\right)$ of the borate minerals in Kramer. They concluded that in the clay-rich B (low-grade borax) zone, the larger short-term variations of $\delta^{11} \mathrm{~B}$ in borax are well accounted for by changes in $\mathrm{pH}$ in a partially desiccating brine (Fig. 15C). It seems likely that this conclusion may also be valid for the other low-grade borax zones $(\mathrm{A}, \mathrm{C})$. Also, they concluded that portions of the $\mathrm{Na}$ borate and $\mathrm{Na}-\mathrm{Ca}$ borate facies consisting of ulexite formed by the reactions of lake brines and groundwater seeping through the lake muds (chemical-primary zone) at the time of lake activity or thereafter, before sediment consolidation.

Smith \& Medrano (1996) proposed that: "(late) reaction diagenesis, resulting from encroaching $\mathrm{Mg}$ - and Ca-bearing groundwater as the once deeply buried orebody was being unroofed, is responsible for some of the peripheral ulexite, as well as most of the colemanite and other $\mathrm{Ca}$ and $\mathrm{Mg}$ borates in the zones". Applied to the Kramer deposit, this interpretation implies that most of the Ca-bearing borates are secondary zones (Fig. 15D).

\section{A LaKe Model For the KirKa Borax SEQuence}

For the Kırka borate deposit, Inan et al. (1973) proposed a perennial lake in which the initial zonation of

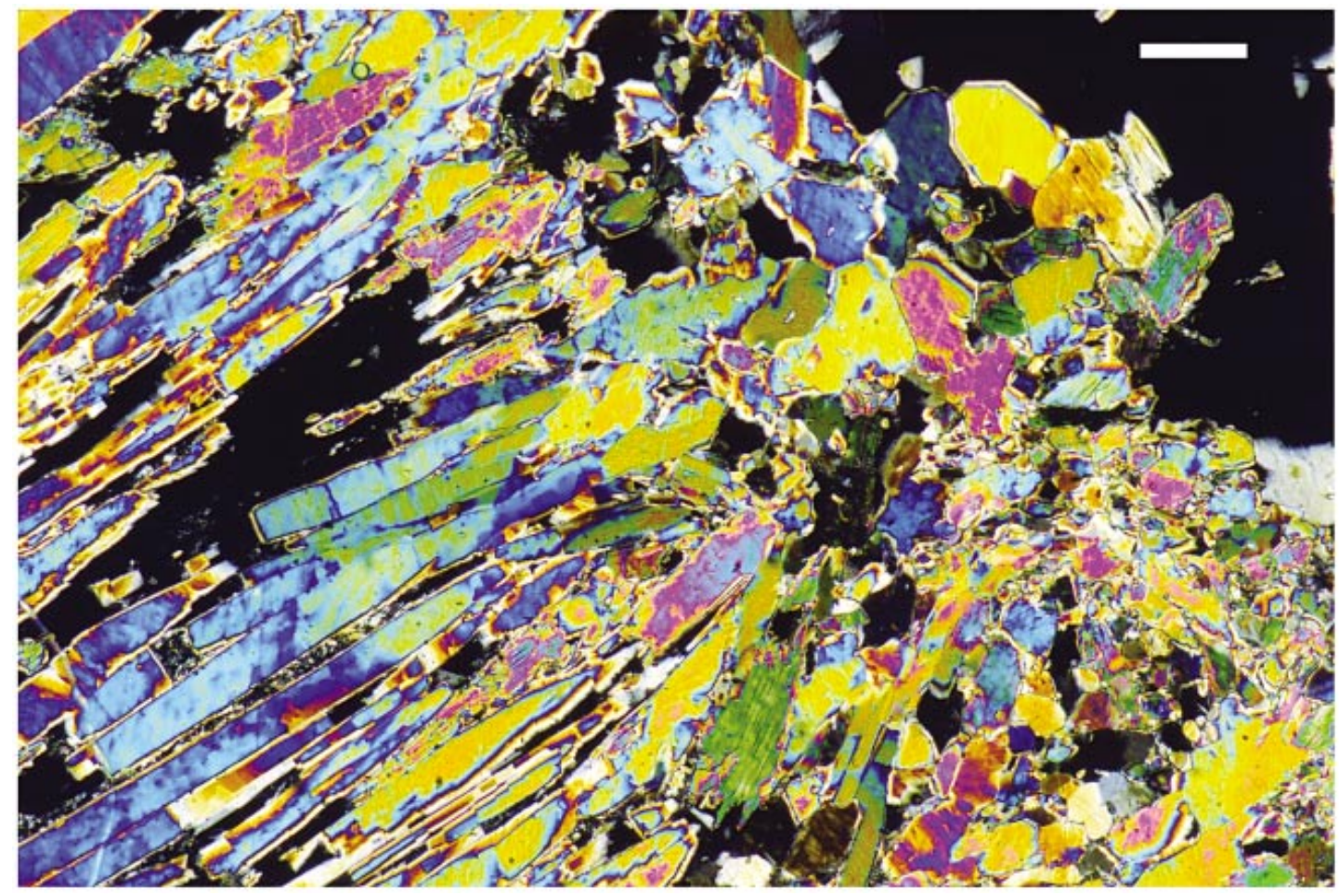

FIG. 14. Tunellite texture composed of long prismatic crystals and a dense mosaic of small, equant crystals. Photomicrograph; crossed nicols. Scale bar: $0.32 \mathrm{~mm}$. 

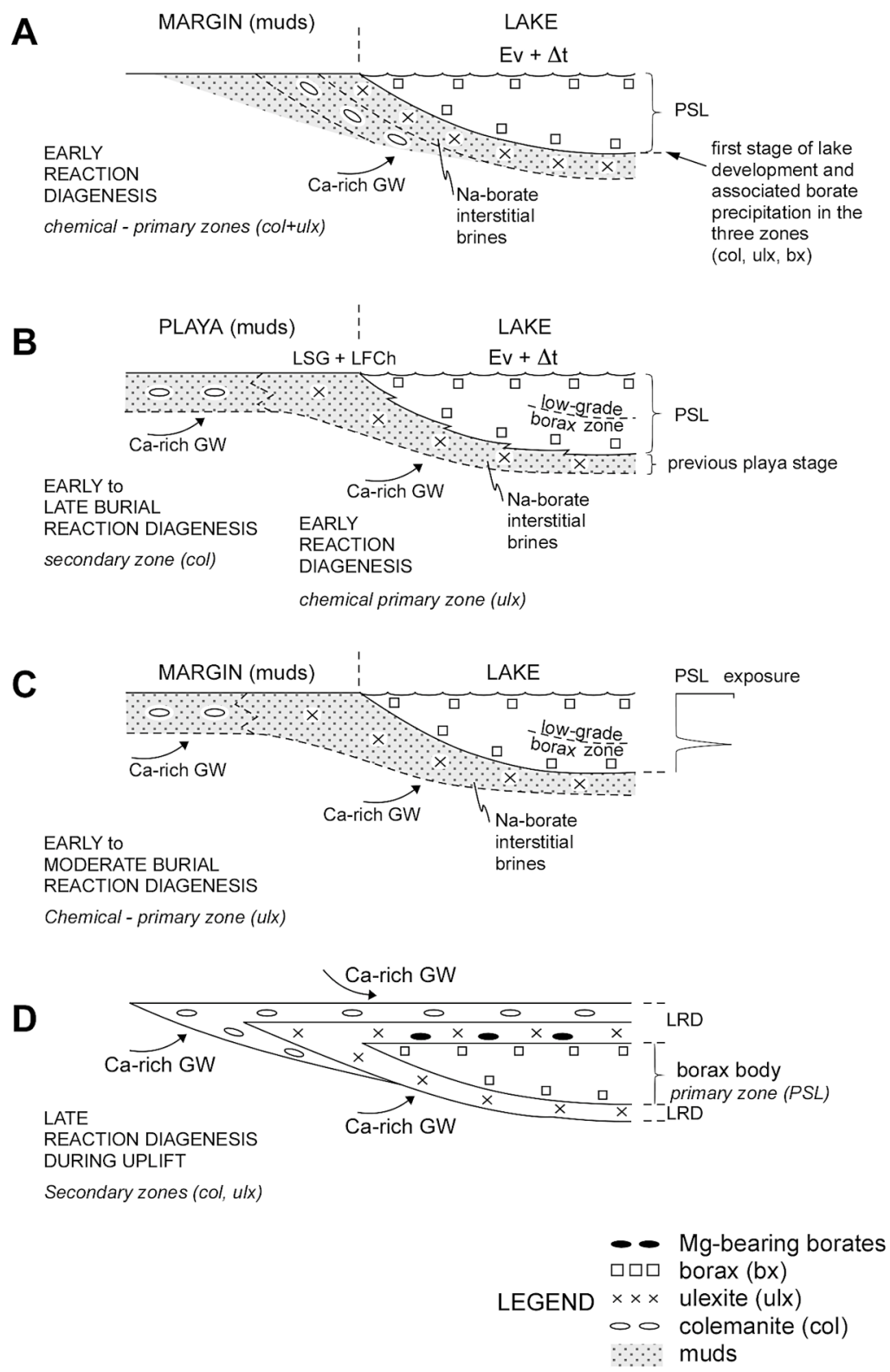

FIG. 15. Diagrams summarizing the most relevant features of some interpretations of the Kramer zoned borate deposit, of Neogene age, in Boron, California. Diagrams A, B and C only represent the deposition at the end of the borax sedimentation. In the three cases, the formation of the subsequent $\mathrm{Na}-\mathrm{Ca}$ - and $\mathrm{Ca}$-borate zones overlying the central body of borax would follow the same pattern as in the underlying zones. Symbols: GW: groundwater, PSL: perennial shallow lake, LSG: lateral salinity gradient, LFCh: lateral facies change, Ev: evaporation influencing the borate precipitation, $\Delta \mathrm{T}$ : temperature changes influencing the borax precipitation, LRD: late reaction diagenesis. (A) Diagram based on Bowser (1965). Subaqueous deposition of borax occurs in the Kramer perennial lake, and early (synsedimentary) reaction diagenesis takes place in the Ca- and $\mathrm{Na}-\mathrm{Ca}$-borate external zones. (B) Diagram based on Barnard \& Kistler (1966). Subaqueous deposition of borax occurs in the Kramer perennial lake; early (synsedimentary) reaction diagenesis occurs in the ulexite zone, and early (synsedimentary) to burial reaction diagenesis takes place in the colemanite zone. (C) Diagram based on Swihart et al. (1996). Subaqueous to exposed deposition of borax occurs in the Kramer lake, and early (synsedimentary) to burial reaction diagenesis takes place in the Ca- and Na-Ca-borate external zones. (D) Diagram based on Smith \& Medrano (1996). Late reaction diagenesis occurs in an undeformed deposit that is being unroofed during exhumation (the deposit is hypothetically similar to that at Kramer). 
minerals (calcite - inyoite - ulexite - borax) occurred on the lake floor under an evaporative control and a lateral gradient of concentration (evaporitic-primary zones). No mention, however, was made of the existence of desiccation phases, or of a temperature control on the crystallization of borax. These authors also assumed a contemporaneous, subaqueous (free) precipitation of inyoite and ulexite at the margins of the lake, and of borax at the center. This last assumption, however, seems to be inappropriate, given the relatively small size of the lake and the presumed homogeneity of the water mass (Fig. 16A). Inan et al. (1973) attributed the most important postdepositional changes in this de- posit (the inyoite-to-colemanite transformation, and the reaction between primary borates and $\mathrm{Mg}$-enriched fluids derived from the clays to form Mg-bearing borates) to interstitial solutions and circulating groundwater, either in the context of syndepositional conditions, or during early or burial diagenesis (secondary zonation).

Smith \& Medrano (1996) agreed that the Kirka deposit accumulated in a perennial, borate-rich lake that periodically (seasonally) precipitated uniformly thick beds of borax. However, these authors considered that the mineral zonation resulted from late reaction-induced diagenesis (secondary zones), as for the rest of the Neogene borate deposits, in general.

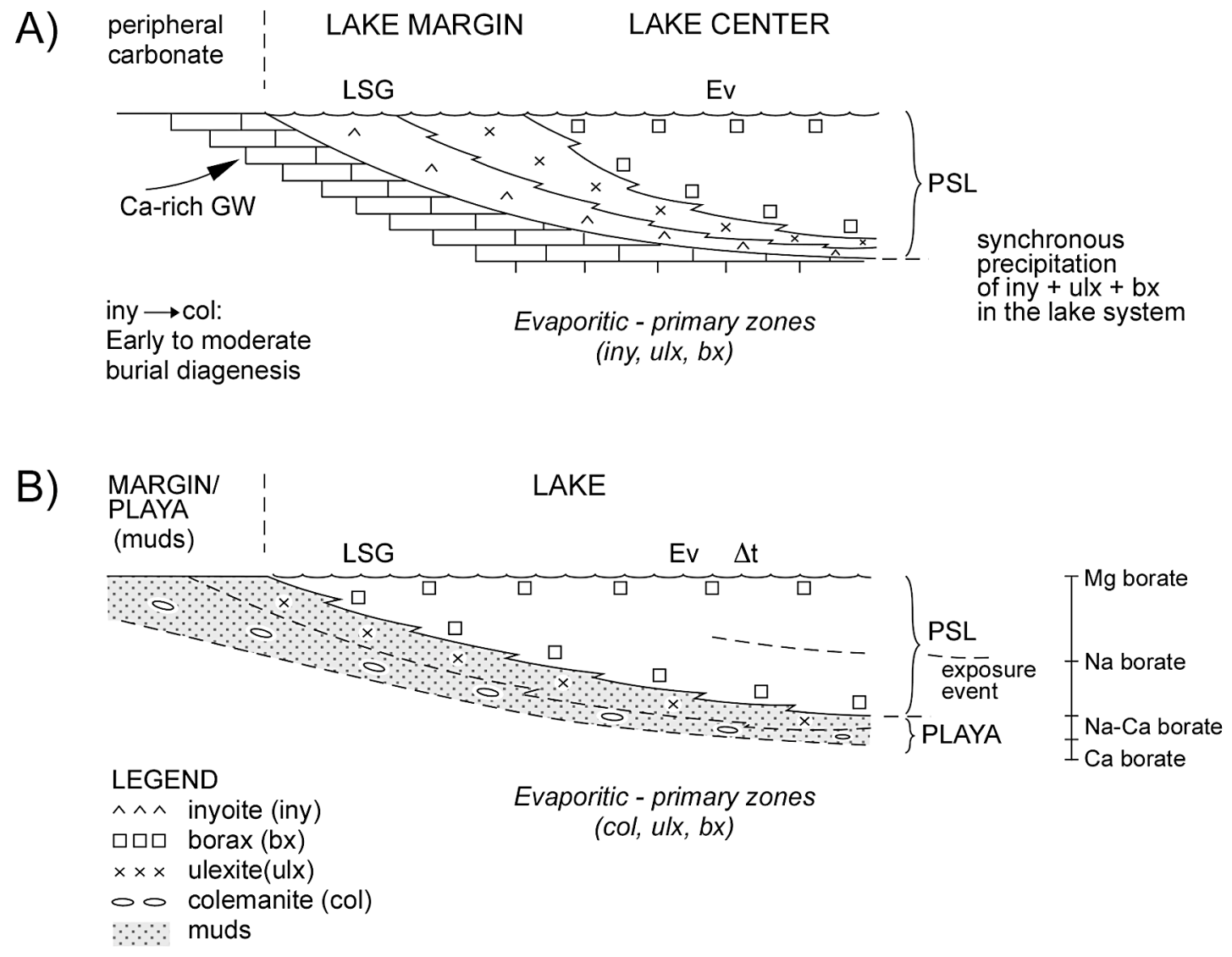

FIG. 16. Diagrams summarizing the most relevant features of two interpretations of the zoned Kırka borate deposit (Miocene, Turkey). In the two cases, the diagrams represent the deposition at the end of the borax sedimentation. In diagram A, the formation of $\mathrm{Na}-\mathrm{Ca}$ - and $\mathrm{Ca}$-borate zones overlying the central body of borax follows the same pattern as in the underlying zones. The same is valid in diagram $\mathrm{B}$, although the $\mathrm{Mg}$-borate layer at the top of the central body (not represented in the diagram) would correspond to a new evaporitic-primary zone in the depositional system. Same symbols as in Figure 15. (A) Diagram based on Inan et al. (1973). Subaqueous deposition of borate occurs in the Kirka perennial lake. No events of exposed deposition are recognized in the lake. (B) Diagram based on Ortí \& Helvacı (2000) and this paper. Subaqueous to exposed deposition of borax occurs in the Kırka lake. Synsedimentary, interstitial crystallization occurs in the external zones containing the $\mathrm{Na}-\mathrm{Ca}$ and $\mathrm{Ca}$ borates (margins of the lake and of playa-lake settings). 
In contrast, Helvaci (1977) proposed a playa-lake setting for the Kurka deposit, and Palmer \& Helvacı (1995, 1997) considered that the mineral zonation is primary: colemanite, ulexite and borax could have precipitated separately from boratiferous solutions with increasing alkalinity under an evaporative control (evaporitic-primary zones). Çolak (1995) interpreted all the borates interbedded with the claystone bed above the borax as deposited in small pools on a playa-lake environment. Ortí \& Helvacı (2000) interpreted as primary the mineral zonation (colemanite - ulexite - borax), and suggested that the borax formed at variable depths in the lake, from relatively deep water to subaerial conditions.

In the interpretation of the borax lake of the Kurka deposit proposed here (Fig. 16B), we also consider an evaporitic-primary origin for the mineral zonation, and combine the presence of a lateral gradient of salinity together with changes in subenvironment from the margins to the lake center (as commonly occurs in other evaporitic lacustrine systems). Massive precipitation of borax was only achieved by intense evaporation acting on a free mass of water during the lake stage, whereas the underground boratiferous brines during both the initial and the final playa-lake stages always remained $\mathrm{Ca}$ rich. During the lake stage, borates of $\mathrm{Ca}$ and $\mathrm{Na}-\mathrm{Ca}$ formed interstitially in an exposed (or very shallow) lake margin, at the same time as free-crystallizing $\mathrm{Na}$ borates occurred in the lake center.

In our interpretation, the carbonate is not viewed as the most external zone of the borate deposit, as claimed by Inan et al. (1973). This is because: (1) the carbonate units underlying and overlying the borate unit have great regional extent and are clearly independent of the local borates; (2) the borate unit is mainly enveloped by claystone beds, and it grades laterally to claystone and marls. Thus, the change from a carbonate to a borate sedimentation in the Kirka lacustrine systems is not viewed as a simple change in the composition of the same lake. Rather, it implies the destruction of the carbonate lake in this area and the progressive installation of a local boratiferous lake. Presumably, this change was caused by regional tectonism or volcanic activity (or both), together with local faulting, hydrologic changes, and a ready supply of boratiferous solutions in the Kirka area.

Other considerations favor the evaporitic-primary interpretation of the external zones in Kirka instead of the mechanisms involved in the early reaction-induced diagenesis:

(1) Above the borax body, it is difficult to envisage the formation of an envelope of ulexite by mixing solutions (chemical-primary zone) once the borax sedimentation was finished and no more Na-borate brine was being generated. However, the presence of such ulexite layers is common to all Neogene deposits, where they are separated from the borax body by claystone beds, devoid of signs of borax replacement by ulexite.
(2) The repetitions, in some Neogene borate formations, of complex elementary sequences cannot be explained satisfactorily by any variant of the reactioninduced diagenesis. In northwestern Argentina, the Miocene Loma Blanca deposit repeats several times the sequence inyoite - ulexite - borax (Alonso et al. 1988) and the thick borate unit of the Monte Amarillo Member in the Miocene Sijes Formation repeats several times the sequence gypsum (+ colemanite) - hydroboracite (+ gypsum) - hydroboracite (Helvac1 \& Alonso 2000, Ortí \& Alonso 2000).

(3) The importance of the marginal zones in some Neogene borate deposits may well have been underestimated. This seems to be the case of the Ca-borate external zone (colemanite) at Kirka.

(4) The consideration of the Ca-borate external zone as a result of reaction-induced diagenesis instead of an evaporitic-primary zone is largely based on the interpretation that colemanite is derived from the transformation of inyoite or from the replacement of ulexite (secondary zone). In contrast, the interpretation of colemanite as a primary borate is based on petrographic and sedimentologic evidence, as mentioned above.

\section{Conclusions}

(1) In the central body of the Miocene Kırka deposit, the various borax-bearing lithofacies (free and interstitially grown precipitates; chemical, clastic and mixed textures) were formed in a lake of variable depth, from very shallow to exposed conditions (playa-lake stage) to relatively deep conditions (perennial lake stage). Evaporative concentration of brine and periodic changes in temperature of the water mass accounted for the crystallization of borax.

(2) Petrographic evidence and estimates of burial depth suggest that both the layers of ulexite and the layers of colemanite are primary precipitates that formed interstitially in the lacustrine muds.

(3) The Mg-bearing borates, which form a discontinuous layer overlying the central body of borax, are considered to be synsedimentary, fractionation-induced precipitates from evolved boratiferous brines.

(4) On the whole, the borax sequence of Kırka represents the initiation of a calcic and sodic-calcic boratiferous playa-lake (interstitial crystallization of colemanite and ulexite), the subsequent development of a perennial borax-producing lake (free crystallization of borax), and the final return to boratiferous playa-lake conditions (interstitial crystallization of $\mathrm{Mg}$-bearing borates, ulexite and colemanite).

(5) The mineral zonation of the Kirka deposit is considered to be primary both from mineralogical (evaporitic-primary zones) and sedimentological (belts of depositional facies) points of view. The concurrence of lake dynamics, intense evaporation and a lateral gradient of salinity can explain the main characteristics of 
the deposit better than any variant of the so-called early reaction diagenesis hypothesis.

(6) The processes attributed in the literature on Neogene borate deposits to late reaction diagenesis (exhumation) can explain only minor features of the distribution of borax in the Kırka borate deposit.

\section{ACKNOWLEDGEMENTS}

We are especially grateful to ETIBANK and the mine manager and geologist for their generosity during field work at the Kırka deposit. We also thank Dr. J. Garcia Veigas and J. Illa (Universitat de Barcelona) for analytical assistance and for preparing the petrographic collection, respectively, and Dr. İ. Gündoğan, Dr. İ. Arpaliyiğit and F. Erkül (Dokuz Eylül University, İzmir) for field assistance. This work was partly financed by the Spanish Ministerio de Ciencia y Tecnología project BTE 2001-3201. We are also indebted to Drs. Mickey Gunter, William M. Last, an anonymous referee, and R.F. Martin for reviewing the manuscript and making helpful suggestions to improve it.

\section{REFERENCES}

ALONSO, R.N. (1986): Ocurrencia, posición estratigráfcia y génesis de los depósitos de boratos de la región de la Puna Argentina. Ph.D. thesis, Universidad Nacional de Salta, Salta, Argentina.

, Helvaci, C., Sureda, RJ. \& Viramonte, J.G. (1988): A new Tertiary borax deposit in the Andes. Mineral. Deposita 23, 299-305.

BARKER, C.E. \& BARKER, J.M. (1985): A re-evaluation of the origin and diagenesis of borate deposits, Death Valley Region, California. In Borates - Economic Geology and Production (J.M. Barker \& S.J. Lefond, eds.). Society of Mining Engineers of the American Institute of Mining, Metallurgical and Petroleum Engineers, New York, N.Y. (101135).

BARNARD, R.M. \& KISTLER, R.B. (1966): Stratigraphic and structural evolution of the Kramer sodium borate ore body, Boron, California. Second Symp. on Salt, 1 (J.L. Rau, ed.). Northern Ohio Geological Society, Cleveland, Ohio (133150).

BowsER, C.J. (1965): Geochemistry and Petrology of the Sodium Borates in the Non-marine Evaporite Environment. $\mathrm{Ph} . \mathrm{D}$. thesis, Univ. of California, Los Angeles, California.

\& DiCKSON, F.W. (1996): Chemical zonation of the borates of Kramer, California. In Second Symposium on Salt 1 (J.L. Rau, ed.). Northern Ohio Geological Society, Cleveland, Ohio (122-132).

CROWLeY, J.K. (1996): Mg- and K-bearing borates and associated evaporites at Eagle Borax Spring, Death Valley, California: a spectrometric exploration. Econ. Geol. 91, 622635 .
ÇOLAK, M. (1995): The Emet and Kırka borate mines (Turkey). 1. Mineralogy and chemistry of the clays. 2. Ceramic application of their tailing products. Institut de Minéralogie et de Pétrographie de l'Université de Fribourg (Suisse), Diss. 1099.

Floyd, P.A., Helvac1, C. \& Mittwede, S.K. (1998): Geochemical discrimination of volcanic rocks associated with borate deposits: an exploration tool? J. Geochem. Explor. 60, 185-205.

Garret, D.E. (1998): Borates. Academic Press, New York, N.Y.

Helvac1, C. (1977): Geology, Mineralogy and Geochemistry of the Borate Deposits and Associated Rocks at the Emet Valley, Turkey. Ph.D. thesis, Univ. of Nottingham, Nottingham, U.K.

(1978): A review of the mineralogy of the Turkish borate deposits. Mercian Geology 6, 257-270.

(1983): Mineralogy of the Turkish borate deposits. Geol. Engineering 17, 37-54.

(1984): Occurrence of rare borate minerals: veatchite-A, tunellite, teruggite and cahnite in the Emet borate deposit, Turkey. Mineral. Deposita 19, 217-226.

(1995): Stratigraphy, mineralogy and genesis of the Bigadiç borate deposits, western Turkey. Econ. Geol. 90, 1237-1260.

\& ALONSO, R.N. (1994): An occurrence of primary inyoite at Lagunita Playa, northern Argentina. In Evaporites and Desert Environments. Proc. $29^{\text {th }}$ Int. Geol. Congress, Part A, 299-303.

$\&$ (2000): Borate deposits of Turkey and Argentina; a summary and geological comparison. Turkish J. Earth Sci. 24, 1-27.

\& Firman, R.J. (1976): Geological setting and mineralogy of Emet borate deposits, Turkey. Trans. Inst. Mining Metall., Appl. Earth Sci. B 85, 142-152.

\& ORTí, F. (1998): Sedimentology and diagenesis of Miocene colemanite-ulexite deposits (western Anatolia, Turkey). J. Sed. Res. 68, 1021-1033.

Stametakis, M.G., Zagouroglou, F. \& Kanaris, J. (1993): Borate minerals and related authigenic silicates in northeastern Mediterranean Late Miocene continental basins. Explor. Mining Geol. 2, 171-178.

\& Yagmurlu, F. (1995): Geological setting and economic potential of the lignite and evaporite-bearing Neogene basins of western Anatolia, Turkey. Isr. Earth Sci. 44, 91-105.

InAN, K. (1972): New borate district, Eskishehir-Kırka Province, Turkey. Trans. Inst. Mining Metall., Appl. Earth Sci. B 81, 163-165. 
Dunham, A.C. \& Esson, J. (1973): Mineralogy, chemistry and origin of Kırka borate deposit, Eskishehir Province, Turkey. Trans. Inst. Mining Metall., Appl. Earth Sci. B-82, 114-123.

Kistler, R.B. \& HelvaC1, C. (1994): Boron and borates. In Industrial Minerals and Rocks ( $6^{\text {th }}$ edition; D.D. Carr, ed.). Society of Mining, Metallurgy and Exploration, Inc. (171186).

LAST, W.M. (1994): Deep-water evaporate mineral formation in lakes of western Canada. In Sedimentology and Geochemistry of Modern and Ancient Saline Lakes (R.W. Renault \& W. Last, eds.). SEPM Spec. Publ. 50, 51-59.

Muessig, S. (1966): Recent South American borate deposits. Second Symposium on Salt 1 (J.L. Rau, ed.). Northern Ohio Geological Society, Cleveland, Ohio (151-159).

ORTí, F. \& Alonso, R.N. (2000): Gypsum-hydroboracite association in the Sijes Formation (Miocene, NW Argentina): implications for the genesis of Mg-bearing borates. J. Sed. Res. 70, 664-681.

\& HelvaC1, C. (2000): Secuencia deposicional de los boratos neogenos de Kırka (Turquia). Geotemas 1, 165169.

Rosell, L. \& GÜNDOGAN, I. (1998): Sulphate-borate relations in an evaporitic lacustrine environment: the Sultançayır Gypsum (Miocene, western Anatolia). Sedimentology 45, 697-710.

Palmer, M.R. \& Helvaci, C. (1995): The boron isotope geochemistry of the Kırka borate deposit, western Turkey. Geochim. Cosmochim. Acta 59, 3599-3605.

\& (1997): The boron isotope geochemistry of the Neogene borate deposits of western Turkey. Geochim. Cosmochim. Acta 61, 3161-3169.
PUEYo, J.J. (1975). Estudio petrológico y geoquímico de los yacimientos potásicos de Cardona, Súria, Sallent y Balsareny (Barcelona, España). Ph.D. thesis, Univ. of Barcelona, Barcelona, Spain.

Rosell, L. \& ORTí, F. (1981-82): The Saline (Potah) Formation of the Navarra Basin (Upper Eocene, Spain). Petrology. Revista Instituto Investigaciones Geológicas, Dip. Prov. Barcelona 35, 71-121.

Smith, G.I. (1985). Borate deposits in the United States: dissimilar in form, similar in geologic setting. In Borates: Economic Geology and Production (J.M. Barker \& S.L. Lefond, eds.). Society of Mining Engineers, New York, N.Y. (37-51)

\& Medrano, M.D. (1996): Continental borate deposits of Cenozoic Age. In Boron: Mineralogy, Petrology and Geochemistry (E.S. Grew \& L.M. Anovitz, eds.). Rev. Mineral. 33, 263-298.

SMITH, W.C. (1960): Borax and borates. In Industrial Minerals and Rocks ( $3^{\text {rd }}$ ed.). Am. Inst. Mining Metall. Eng. (103122).

Sun, D. \& LI, B. (1993): Origins of borates in the saline lakes of China. In Seventh Symposium on Salt 1. Elsevier, Amsterdam, The Netherlands (177-193)

SUNDER, M.S. (1980): Geochemistry of the Sarikaya borate deposit (Kırka-Eskishehir). Bull. Geol. Congress Turkey 2 , 19-34.

Swihart, G.H., McBay, E.H., Smith, D.H. \& Siefre, J.W (1996): A boron isotopic study of a mineralogically zoned lacustrine borate deposit: the Kramer deposit, California U.S.A. Chem. Geol. (Isotope Geosci. Sect.) 127, 241-250.

Received November 15, 2003, revised manuscript accepted June 1, 2004. 